\title{
2,6-Bis(oxazolinyl)phenylnickel(II) Bromide and 2,6-Bis(ketimine)phenylnickel(II) Bromide: Synthesis, Structural Features, and Redox Properties ${ }^{\text {th }}$
}

\author{
Marianne Stol, ${ }^{\dagger} \dagger$ Dennis J. M. Snelders, ${ }^{\dagger}$ Meenal D. Godbole, ${ }^{\S}$ Remco W. A. Havenith,, \\ David Haddleton, ${ }^{\perp}$ Guy Clarkson, ${ }^{\perp}$ Martin Lutz, ${ }^{\triangle}$ Anthony L. Spek, $, \Delta, \#$ \\ Gerard P. M. van Klink, ${ }^{\dagger}$ and Gerard van Koten*, ${ }^{\dagger}$ \\ Organic Chemistry and Catalysis, Faculty of Science, Utrecht University, Padualaan 8, 3584 CH Utrecht, \\ The Netherlands, Dutch Polymer Institute, P.O. Box 902, 5600 AX Eindhoven, The Netherlands, \\ Leiden Institute of Chemistry, Gorleaus Laboratories, Leiden University, P.O. Box 9502, 2300 RA Leiden, \\ The Netherlands, Theoretical Chemistry Group, Faculty of Science, Utrecht University, Padualaan 8, \\ 3584 CH Utrecht, The Netherlands, Department of Chemistry, Warwick University, Coventry CV4 7Al, \\ United Kingdom, and Crystal and Structural Chemistry, Faculty of Science, Utrecht University, \\ Padualaan 8, $3584 \mathrm{CH}$ Utrecht, The Netherlands
}

Received November 16, 2006

\begin{abstract}
2,6-Bis(oxazolinyl)phenylnickel bromide complexes [NiBr(R,R'-Phebox)] (2) were synthesized via two synthetic routes (A and $\mathrm{B})$. In route $\mathrm{A}$, selective bis-ortho lithiation of [R, $\mathrm{R}^{\prime}$-PheboxBr], followed by a transmetalation reaction with [ $\left.\mathrm{NiBr}_{2}\left(\mathrm{PEt}_{3}\right)_{2}\right]$, yielded not only complexes 2 with an $\eta^{3}$-mer- $N, C, N^{\prime}$-bonded Phebox ligand but also $\left[\mathrm{NiBr}\left(\mathrm{R}, \mathrm{R}^{\prime}-\mathrm{Phebox}\right)\left(\mathrm{PEt}_{3}\right)_{2}\right]$, 7, where the nickel center is $\eta^{1}$ - $C$ bonded to the intra-annular $\mathrm{C}_{i p s o}$ of the Phebox ligand. Coordination of two $\mathrm{PEt}_{3}$ ligands completes the square-planar coordination sphere of the $\mathrm{Ni}$ center in 7. When $\mathrm{R}=t$ - $\mathrm{Bu}, \mathrm{R}^{\prime}=\mathrm{H}$, only complex 7c was formed. Alternatively, when route B (oxidative addition with $\left[\mathrm{Ni}(\operatorname{cod})_{2}\right]$, cod $=$ cyclooctadiene) was followed, selective formation of complexes 2 was observed. X-ray crystal structures were obtained for [ $\mathrm{NiBr}-$ (i-Pr,H-Phebox)] (2b) and [NiBr(bis(ketimine)phenyl)] (3). The Ni centers have square-planar geometries with a planar, $\eta^{3}$-mer- $N, C, N^{\prime}$ coordination of the terdentate ligand systems. Complexes $\mathbf{2}$ were found to be inactive as catalysts in the atom-transfer radical polymerization (ATRP) reaction of methyl methacrylate (MMA) and in the atom-transfer radical addition (ATRA, Kharasch addition) reaction of $\mathrm{CCl}_{4}$ to MMA. This is ascribed to the relatively high oxidation potential of $\mathrm{Ni}^{\mathrm{II}}-$ Phebox complexes, which excludes the (reversible) formation of a $\mathrm{d}^{7}-\mathrm{Ni}^{\mathrm{III}}-$ Phebox complex, a crucial condition for subsequent reactions. Cyclovoltammetry $(\mathrm{CV})$ experiments $\left((n-\mathrm{Bu})_{4} \mathrm{NBr}\right.$ as supporting electrolyte $)$ showed no electrochemical waves between -1.00 and $+1.50 \mathrm{~V}\left(\mathrm{Ag} / \mathrm{AgCl}\right.$ reference electrode, $(n-\mathrm{Bu})_{4} \mathrm{NBr}$ as supporting electrode). Theoretical calculations showed that the energy $\left(E_{\mathrm{ox}}\right)$ needed for the oxidation reaction occurring during the $\mathrm{CV}$ experiments is considerably higher for $[\mathrm{NiBr}(\mathrm{Me}, \mathrm{Me}-\mathrm{Phebox})](1.87 \mathrm{eV})$ and $[\mathrm{NiBr}($ bis(ketimine)phenyl)] $(1.90 \mathrm{eV})$ than for $[\mathrm{NiBr}(\mathrm{NCN})](\mathbf{1})(1.45 \mathrm{eV})$.
\end{abstract}

\section{Introduction}

Chelating aryl ligands have become an important class of ligands in homogeneous catalysis ${ }^{1}$ and materials chemistry. ${ }^{1 b, 2}$ We and others have extensively studied metal complexes derived from the so-called ECE pincer ligand (ECE is $\left[\mathrm{C}_{6} \mathrm{H}_{3}\left(\mathrm{CH}_{2} \mathrm{E}\right)_{2^{-}}\right.$ $2,6]^{-}$in which $\mathrm{E}$ is $\mathrm{NR}_{2}\left(\mathbf{A},{ }^{1-3}\right.$ Figure 1$\left.), \mathrm{PR}_{2}, \mathrm{SR}, \mathrm{OMe}\right)$. The

Dedicated to Professor Miguel Yus on the occasion of his 60th birthday in recognition of his skills and contribution to the field of organic chemistry.

* Author to whom correspondence should be addressed. E-mail: g.vankoten@uu.nl.Fax: +31-30-2523615. Tel: +31-30-2533120.

Organic Chemistry and Catalysis, Utrecht University.

$\doteqdot$ Dutch Polymer Institute.

$\S$ Leiden University.

" Theoretical Chemistry Group, Utrecht University.

$\perp$ Warwick University.

${ }^{\triangle}$ Crystal and Structural Chemistry, Utrecht University.

\# Author to whom crystallographic inquiries may be directed. E-mail: a.1.spek@chem.uu.nl.

(1) (a) Singleton, J. T. Tetrahedron 2003, 59, 1837. (b) Albrecht, M.; van Koten, G. Angew. Chem., Int. Ed. 2001, 40, 3750. (c) van der Boom, M. E.; Milstein, D. Chem. Rev. 2003, 103, 1759.

(2) (a) Albrecht, M.; Rodríguez, G.; Schoenmaker, J.; van Koten, G. Org. Lett. 2000, 2, 3461. (b) Guillena, G.; Kruithof, C. A.; Casado, M. A.; Egmond, M. R.; van Koten, G. J. Organomet. Chem. 2003, 668, 3.
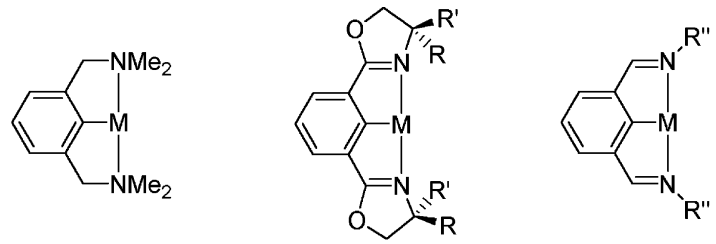

A $M(N C N)$

B M(Phebox)

C M(aldimine-NCN)

$\mathrm{M}=\mathrm{Ni}, \mathrm{Pd}, \mathrm{Pt}, \mathrm{Rh}$, etc. $\quad \mathrm{M}=\mathrm{Ni}, \mathrm{Pd}, \mathrm{Pt}, \mathrm{Rh}, \mathrm{Li}$

$M=P d, P t, R h$

Figure 1. $N, C, N^{\prime}$-terdentate coordinating ligand systems applied in organometallic complexes.

ECE pincer ligands have a rich coordination chemistry originating from the conformational flexibility of the $\mathrm{CH}_{2} \mathrm{E}$ ortho substituents. The bis(ortho-oxazolinyl)phenyl or Phebox ligand $\left(\mathbf{B},{ }^{4,5,6,7}\right.$ Figure 1) and the bis(aldimine)phenyl ligand $\left(\mathbf{C},{ }^{8}\right.$ Figure 1) have ortho substituents with a pronounced restriction of conformational freedom; that is, only rotation about $\mathrm{C}_{\text {aryl }}-\mathrm{C}_{\text {imine }}$ is possible as well as syn/anti configurations (for $\mathbf{C}$ ). The

(3) (a) van Koten, G. Pure Appl. Chem. 1989, 61, 1681. (b) Rietveld, M. H. P.; Grove, D. M.; van Koten, G. New J. Chem. 1997, 21, 751. 
oxazolinyl $\mathrm{C}=\mathrm{N}$ groupings in these ligands have the tendency to be coplanar with the arene ring, thus creating a planar NCNterdentate ligand system. This has been observed in $\mathrm{Rh}-{ }^{4}$ $\mathrm{Ni}-{ }^{5} \mathrm{Pd}-{ }^{4 a, b, 6}$ and $\mathrm{Pt}-\mathrm{Phebox}^{4 \mathrm{~b}, 7}$ derivatives and in $\mathrm{Li}$-Phebox compounds in which $\mathrm{C}_{i p s o}$ is three-center twoelectron bonded to two lithium atoms in a dimeric structure. ${ }^{9}$ Nevertheless, the Phebox ligand can also be $\eta^{1}-C$ bonded to a metal center, as has been found for $[\mathrm{Au}(\mathrm{Me}, \mathrm{Me}-\mathrm{Phebox})$ $\left.\left(\mathrm{PPh}_{3}\right)\right]^{10}$ and $\left[\mathrm{Sn}(\mathrm{Me}, \mathrm{Me}-\mathrm{Phebox}) \mathrm{Me}_{3}\right] \cdot{ }^{9}$

The Phebox ligand attracted much attention because of the ample opportunities to introduce chirality in the oxazoline ring by the use of readily available chiral amino alcohols in the oxazolinyl substituent synthesis. In 1997, the Phebox ligand was introduced in catalysis by Denmark (cyclopropanation with Phebox $-\mathrm{Pd}$ complexes) ${ }^{6 a}$ and was studied extensively by Nishiyama, ${ }^{4,7 a}$ who employed Phebox $-\mathrm{Rh},-\mathrm{Pd}$, and $-\mathrm{Pt}$ complexes in catalysis (asymmetric aldol-type condensation of isocyanides and aldehydes, ${ }^{4 \mathrm{~b}, \mathrm{c}}$ asymmetric Michael addition, ${ }^{4 \mathrm{e}}$ enantioselective allylation of aldehydes, ${ }^{4 \mathrm{~d}, 11}$ and asymmetric alkylation of aldimines ${ }^{7 a}$ ).

In the search for catalytic properties of $E, C, E^{\prime}$-pincer metal complexes, the unique atom-transfer radical addition (abbreviated as ATRA, 1:1 addition of $\mathrm{CClX}_{3}$ to MMA) ${ }^{12}$ and atomtransfer radical polymerization (abbreviated as ATRP, polymerization of MMA $)^{13}$ reactions catalyzed by $\left[\mathrm{NiBr}\left(\mathrm{C}_{6} \mathrm{H}_{3}\right.\right.$ $\left.\left.\left(\mathrm{CH}_{2} \mathrm{NMe}_{2}\right)_{2}-2,6\right)\right](\mathbf{1}, \mathbf{A}(\mathrm{M}=\mathrm{NiBr}$, see Figure 1)) were

(4) (a) Motoyama, Y.; Makihara, N.; Mikami, Y.; Aoki, K.; Nishiyama, H. Chem. Lett. 1997, 951. (b) Motoyama, Y.; Kawakami, H.; Shimozono, K.; Aoki, K.; Nishiyama, H. Organometallics 2002, 21, 3408. (c) Motoyama, Y.; Shimozono, K.; Aoki, K.; Nishiyama, H. Organometallics 2002, 21, 1684. (d) Motoyama, Y.; Okano, M.; Narusawa, H.; Makihara, N.; Aoki, K.; Nishiyama, H. Organometallics 2001, 20, 1580. (e) Motoyama, Y.; Koga, Y.; Kobayashi, K.; Aoki, K.; Nishiyama, H. Chem.-Eur. J. 2002 $8,2968$.

(5) Fossey, J. S.; Richards, C. J. J. Organomet. Chem. 2004, 689, 3056. (6) (a) Denmark, S. E.; Stavenger, R. A.; Faucher, A.-M.; Edwards, J. P. J. Org. Chem. 1997, 62, 3375. (b) Stark, M. A.; Jones, G.; Richards, C. J. Organometallics 2000, 19, 1282.

(7) (a) Motoyama, Y.; Mikami, Y.; Kawakami, H.; Aoki, K.; Nishiyama, H. Organometallics 1999, 18, 3584. (b) Fossey, J. S.; Richards, C. J. Organometallics 2004, 23, 367.

(8) (a) Hoogervorst, W. J.; Elsevier, C. J.; Lutz, M.; Spek, A. L. Organometallics 2001, 20, 4437. (b) Hoogervorst, W. J.; Koster, A. L.; Lutz, M.; Spek, A. L.; Elsevier, C. J. Organometallics 2004, 23, 1161. (c) Hoogervorst, W. J.; Goubitz, K.; Fraanje, J.; Lutz, M.; Spek, A. L.; Ernsting, J. M.; Elsevier, C. J. Organometallics 2004, 23, 4550. (d) Hoogervorst, W. J. Isophthalaldimine Compounds of Palladium, Platinum and Rhodium. Thesis, 2003, Universiteit van Amsterdam, Amsterdam, The Netherlands. (e) Vila, J. M.; Gayoso, M.; Pereira, T.; López Torres, M.; Fernández, J. J.; Fernández, A.; Ortigueira, J. M. J. Organomet. Chem. 1996, 506, 165 (f) Fossey, J. S.; Richards, C. J. Organometallics 2002, 21, 5259.

(9) Stol, M.; Snelders, D. J. M.; de Pater, J. J. M.; van Klink, G. P. M.; Kooijman, H.; Spek, A. L.; van Koten, G. Organometallics 2005, 24, 743. (10) Stol, M.; Lutz, M.; Spek, A. L.; van Klink, G. P. M.; van Koten,

G. To be published.

(11) (a) Motoyama, Y.; Narusawa, H.; Nishiyama, H. Chem. Commun. 1999, 131. (b) Motoyama, Y.; Nishiyama, H. Synlett 2003, 12, 1883.

(12) (a) van de Kuil, L. A.; Veldhuizen, Y. S. J.; Grove, D. M.; Zwikker, J. W.; Jenneskens, L. W.; Drenth, W.; Smeets, W. J. J.; Spek, A. L.; van Koten, G. Recl. Trav. Chim. Pays-Bas 1994, 113, 267. (b) Knapen, J. W. J.; van der Made, A.; de Wilde, J. C.; van Leeuwen, P. W. N. M.; Wijkens, P.; Grove, D. M.; van Koten, G. Nature 1994, 372, 659. (c) van de Kuil, L. A.; Grove, D. M.; Gossage, R. A.; Zwikker, J. W.; Jenneskens, L. W.; Drenth, W.; van Koten, G. Organometallics 1997, 16, 4985. (d) Gossage, R. A.; van de Kuil, L. A.; van Koten, G. Acc. Chem. Res. 1998, 31, 423. (e) Grove, D. M.; van Koten, G.; Verschuuren, A. H. M. J. Mol. Catal. 1988, 45, 169. (f) Grove, D. M.; Verschuuren, A. H. M.; van Koten, G.; van Beek, J. A. M. J. Organomet. Chem. 1989, 372, C1. (g) Kleij, A. W.; Gossage, R. A.; Klein Gebbink, R. J. M.; Brinkmann, N.; Reijerse, E. J.; Kragl, U.; Lutz, M.; Spek, A. L.; van Koten, G. J. Am. Chem. Soc. 2000 , 122, 12112. (h) Kleij, A. W.; Gossage, R. A.; Jastrzebski, J. T. B. H.; Boersma, J.; van Koten, G. Angew. Chem., Int. Ed. 2000, 39, 176. (i) Gossage, R. A.; Jastrzebski, J. T. B. H.; van Ameijde, J.; Mulders, S. J. E.; Brouwer, A. J.; Liskamp, R. M. J.; van Koten, G. Tetrahedron Lett. 1999, 40, 1413.

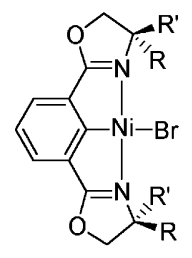

2a $\mathrm{R}=\mathrm{R}^{\prime}=\mathrm{Me}$ 2b $R=i \operatorname{Pr}, R^{\prime}=H$

2c $R=t B u, R^{\prime}=H$

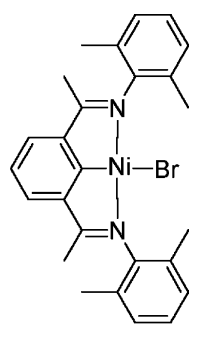

3
Figure 2. [ $\mathrm{NiBr}(\mathrm{Phebox})]$ (2) and [ $\mathrm{NiBr}$ (bis(ketimine)phenyl)] (3).

discovered. Extensive studies revealed that both the ATRP and ATRA reactions are catalyzed by these $\mathrm{Ni}$ compounds because of (i) the low and reversible $\mathrm{Ni}^{\mathrm{II}} \rightarrow \mathrm{Ni}^{\mathrm{III}}$ oxidation potential and (ii) the persistence of a d $\mathrm{d}^{7} \mathrm{Ni}{ }^{\mathrm{III}}$ species $\left[\mathrm{Ni}^{\mathrm{III}} \mathrm{X}_{2}\left(\mathrm{C}_{6} \mathrm{H}_{3}\right.\right.$ $\left.\left.\left(\mathrm{CH}_{2} \mathrm{NMe}_{2}\right)_{2}-2,6\right)\right]$. So far, this catalytic reactivity was not found for PCP- and SCS-nickel complexes and seems to be unique for the NCN-nickel complexes. Accordingly, we set out to study the synthesis and properties of other $\mathrm{Ni}^{\mathrm{II}}$ complexes with $N, C, N^{\prime}$ terdentate coordinating ligands related to $\mathbf{1}$, i.e., the $\mathrm{Ni}-\mathrm{Phebox}$ (2) and Ni-ketimine (3) NCN complexes, both with restricted conformational freedom as compared to $\left[\mathrm{NiBr}\left(\mathrm{C}_{6} \mathrm{H}_{3}-\right.\right.$ $\left.\left.\left(\mathrm{CH}_{2} \mathrm{NMe}_{2}\right)_{2}-2,6\right)\right](\mathbf{1}$, abbreviated as $[\mathrm{NiBr}(\mathrm{NCN})]$.

Here, the synthesis of $\left[\mathrm{NiBr}\left(\mathrm{R}, \mathrm{R}^{\prime}-\mathrm{Phebox}\right)\right]$ and $[\mathrm{NiBr}($ bis(ketimine)phenyl)] complexes (Figure 2) and analysis of their structural properties are described. The $\mathrm{Ni}-$ ketimine complex 3 is closely related to the 2,6-bis(aldimine)phenyl- $\mathrm{Pd},-\mathrm{Pt}$, and - Rh complexes, recently described by Elsevier et al. (C, Figure 1). ${ }^{8}$ In addition the catalytic activity of $\mathbf{2}$ in the radical polymerization of methyl methacrylate (MMA) and the Kharasch addition of $\mathrm{CCl}_{4}$ to MMA has been tested. The redox properties of $\left[\mathrm{NiBr}\left(\mathrm{R}, \mathrm{R}^{\prime}\right.\right.$-Phebox) $]$ (2) and [ $\mathrm{NiBr}$ (bis(ketimine)phenyl)] (3) are compared to those of $[\mathrm{NiBr}(\mathrm{NCN})]$ (1). Theoretical calculations provide further insight into the redox properties of $\mathbf{2}$ and $\mathbf{3}$, which have implications for their reactivity in ATRA and ATRP.

\section{Results and Discussion}

Ligand Synthesis. Three different Phebox ligands (5) were synthesized using modified literature procedures. ${ }^{14-16}$ One achiral Phebox ligand (5a) was derived from 2-amino-2-methyl1-propanol, and the two chiral Phebox ligands (5b, 5c, respectively, Scheme 1) were obtained from L-valinol and L-tertleucinol, respectively. Synthesis of 2,6-bis $\left(4,4^{\prime}-\mathrm{R}, \mathrm{R}^{\prime}-2^{\prime}\right.$-oxazolinyl)phenyl bromide 5a $\left(\mathrm{R}=\mathrm{R}^{\prime}=\mathrm{Me}\right), \mathbf{5 b}\left(\mathrm{R}=i-\mathrm{Pr}, \mathrm{R}^{\prime}=\mathrm{H}\right)$, and $\mathbf{5 c}\left(\mathrm{R}=t\right.$-Bu, $\left.\mathrm{R}^{\prime}=\mathrm{H}\right)$ (abbreviated as $\left[\mathrm{R}, \mathrm{R}^{\prime}\right.$-PheboxBr]) started with the oxidation of 1-bromo-2,6-dimethylbenzene with $\mathrm{KMnO}_{4}$ to 2-bromoisophthalic acid. ${ }^{14}$ The latter acid was chlorinated with $\mathrm{SOCl}_{2}$, followed by reaction of the resulting 2-bromoisophthaloyl chloride (4) with the appropriate amino alcohol. ${ }^{15}$ The resulting amide was cyclized in situ via a procedure of Vorbrüggen using a $\mathrm{CCl}_{4} / \mathrm{PPh}_{3}$ reagent. ${ }^{16}$

The synthesis of 2,6-bis[ $N, N^{\prime}$-(2',6'-dimethylphenyl)ketimino]phenyl bromide $(\mathbf{6}$, abbreviated as [bis(ketimine)phenylBr])

(13) (a) Granel, C.; Dubois, Ph.; Jérôme, R.; Teyssié, Ph. Macromolecules 1996, 29, 8576. (b) Granel, C.; Teyssié, Ph.; Jérôme, R.; Nicol, P. (Elf Atochem S. A., France) Eur. Pat. Appl. EP796870, 1999. (c) Granel, C.; Moineau, G.; Lecomte, Ph.; Dubois, Ph.; Jérôme, R.; Teyssié, Ph. Polym. Prepr. 1997, 38, 450 .

(14) Rodríguez, G.; Albrecht, M.; Schoenmaker, J.; Ford, A.; Lutz, M.; Spek, A. L.; van Koten, G. J. Am. Chem. Soc. 2002, 124, 5127.

(15) Motoyama, Y.; Okano, M.; Narusawa, H.; Makihara, N.; Aoki, K.; Nishiyama, H. Organometallics 2001, 20, 1580.

(16) Vorbrüggen, H.; Krolikiewicz, K. Tetrahedron 1993, 49, 9353. 
Scheme 1. Synthesis of $\left[R, R^{\prime}-P h e b o x B r\right](5)$

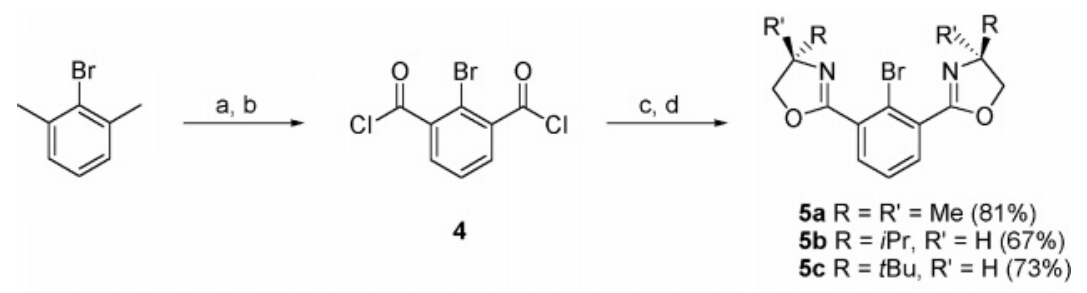

a) $\mathrm{KMnO}_{4}, \mathrm{tBuOH}, \mathrm{H}_{2} \mathrm{O}, 76 \%$; b) $\mathrm{SOCl}_{2}$, quant.; c) amino alcohol, $\mathrm{Et}_{3} \mathrm{~N}, \mathrm{CH}_{2} \mathrm{Cl}_{2}$, not isolated; d) $\mathrm{PPh}_{3}, \mathrm{CCl}_{4}, \mathrm{Et}_{3} \mathrm{~N}, \mathrm{CH}_{3} \mathrm{CN}$.

Scheme 2. Synthesis of [Bis(ketimine)phenylBr] (6)

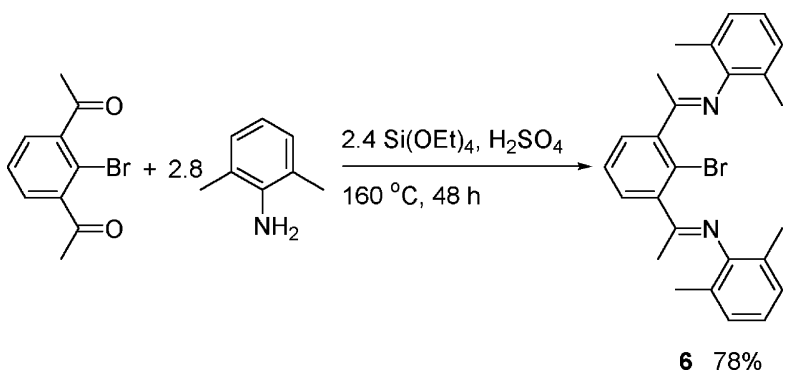

could not be accomplished via common condensation procedures: precipitation of the product, as was used for the 2,6bis(ketimine)pyridine analogue, ${ }^{17}$ or via removal of the generated $\mathrm{H}_{2} \mathrm{O}$ by azeotropic distillation using a trap (Dean Stark). The synthesis of $\mathbf{6}$ was successfully accomplished by reacting 2,6-diacetylphenyl bromide ${ }^{18}$ with 2.8 equiv of 2,6-dimethylaniline, in the presence of $\mathrm{Si}(\mathrm{OEt})_{4}$, under removal of ethanol at high temperature (Scheme 2).

This procedure was developed for the synthesis of sterically hindered imines, ${ }^{19}$ and these forcing conditions are necessary indeed to obtain the bis(ketimine)phenyl bromides such as 6.

Synthesis of Ni Complexes 2 and 3. Starting from [R, R'PheboxBr] 5, synthesis of the Phebox-Ni complexes was accomplished via two different synthetic routes. Route A involved selective bis-ortho lithiation followed by transmetalation of the in situ formed Phebox - Li with, e.g., $\left[\mathrm{NiBr}_{2}\left(\mathrm{PEt}_{3}\right)_{2}\right]$. In a previous paper we demonstrated that selective bis-ortho

(17) (a) Brookhart, M. S.; Small, B. L. (E. I. Du Pont de Nemours \& Co., U.S.A.) PCT Int. Appl. WO9830612, 1998. (b) Bennet, A. M. A. (E. I. Du Pont de Nemours \& Co., U.S.A.) PCT Int. Appl. WO9827124, 1998. (c) Small, B. L.; Brookhart, M.; Bennett, A. M. A. J. Am. Chem. Soc. 1998 120, 4049. (d) Britovsek, G. J. P.; Gibson, V. C.; Kimberley, B. S.; Maddox, P. J.; McTavish, S. J.; Solan, G. A.; White, A. J. P.; Williams, D. J. Chem. Commun. 1998, 849. (e) Small, B. L.; Brookhart, M. J. Am. Chem. Soc. 1998, 120, 7143. (f) Britovsek, G. J. P.; Bruce, M.; Gibson, V. C.; Kimberley, B. S.; Maddox, P. J.; Mastroianni, S.; McTavish, S. J.; Redshaw, C.; Solan, G. A.; Strömberg, S.; White, A. J. P.; Williams, D. J. J. Am. Chem. Soc. 1999, 121, 8728. (g) Britovsek, G. J. P.; Spitzmesser, S. K. (BP Chemicals Limited, GB) PCT Int. Appl. WO0069869, 2000. (h) Britovsek, G. J. P.; Mastroianni, S.; Solan, G. A.; Baugh, S. P. D.; Redshaw, C.; Gibson, V. C.; White, A. J. P.; Williams, D. J.; Elsegood, M. R. J. Chem.-Eur. J. 2000, 6, 2221. (i) Watanabe, M.; Sato, H.; Kuramoto, M.; Tanaka, S.; Tamura, T. (Idemitsu Petrochemical Co., Ltd., Japan) PCT Int. Appl. WO2001036379, 2001. (j) Kooistra, T. M.; Knijnenburg, Q.; Smits, J. M. M.; Horton, A. D.; Budzelaar, P. H. M.; Gal, A. W. Angew. Chem., Int. Ed. 2001, 40, 4719. (k) Gibson, V. C.; Humphries, M. J.; Tellmann, K. P.; Wass, D. F.; White, A. J. P.; Williams, D. J. Chem. Commun. 2001, 2252. (1) Small, B. L.; Marcucci, A. J. Organometallics 2001, 20, 5738 (m) Schmidt, R.; Welch, M. B.; Palackal, S. J.; Alt, H. G. J. Mol. Catal. A 2002, 179, 155. (n) Abu-Surrah, A. S.; Lappalainen, K. Piironen, U.; Lehmus, P.; Repo, T.; Leskelä, M. J. Organomet. Chem. 2002, 648, 55. (o) Babik, S. T.; Fink, G. J. Organomet. Chem. 2003, 683 (1), 209. (p) Small, B. L. Organometallics 2003, 22, 3178.

(18) Déziel, R.; Malenfant, E.; Bélanger, G. J. Org. Chem. 1996, 61, 1875 .

(19) Love, B. E.; Ren, J. J. Org. Chem. 1993, 58, 5556. lithiation of $\mathbf{5}$ via $\mathrm{Br}-\mathrm{Li}$ exchange can be achieved with $n$-BuLi in $\mathrm{Et}_{2} \mathrm{O}$ at $-78^{\circ} \mathrm{C} .{ }^{9}$ Reaction of either [Me,Me-PheboxBr] (5a) or $[i-\mathrm{Pr}, \mathrm{H}-\mathrm{PheboxBr}](\mathbf{5 b})$ with $n$-BuLi and subsequent reaction with $\left[\mathrm{NiBr}_{2}\left(\mathrm{PEt}_{3}\right)_{2}\right]$ resulted in the formation of $[\mathrm{NiBr}(\mathrm{Me}, \mathrm{Me}-$ Phebox)] (2a) and [NiBr( $i$-Pr,H-Phebox)] (2b), respectively, which could be isolated as pure products. A disadvantage of this route is that in addition to the desired $\eta^{3}$-mer- $N, C, N^{\prime}$ Phebox $-\mathrm{NiBr}$ complexes 2, $\eta^{1}-C$-Phebox $-\mathrm{NiBr}\left(\mathrm{PEt}_{3}\right)_{2}$ complexes of type $\mathbf{7}$ are also formed. The amount of $\mathbf{7}$ seems to be dependent on the nature of the oxazolinyl substituents $\mathrm{R}$ and $\mathrm{R}^{\prime}$. In the reactions to $\mathbf{2} \mathbf{a}$ and $\mathbf{2 b}, \mathbf{7} \mathbf{a}$ and $\mathbf{7 b}$, respectively, were formed as side products in relatively small amounts (max. 26\%), while 7c was formed exclusively in the transmetalation reaction of $\mathbf{5 c}$ with $\left[\mathrm{NiBr}_{2}\left(\mathrm{PEt}_{3}\right)_{2}\right]$. In the latter reaction, formation of the desired product $2 \mathrm{c}$ was not even observed.

Isolation of side products $\mathbf{7 a}$ and $\mathbf{7 b}$ was hampered because of similar solubility properties to the starting complex $\left[\mathrm{NiBr}_{2}-\right.$ $\left.\left(\mathrm{PEt}_{3}\right)_{2}\right]$. However, 7c could be isolated pure as a dark red solid. ${ }^{31} \mathrm{P}\left\{{ }^{1} \mathrm{H}\right\}$ spectra (singlet at $\delta 1.4 \mathrm{ppm}$ ) showed that the two $\mathrm{PEt}_{3}$ ligands are trans-coordinated. The $\left[\mathrm{NiBr}(t-\mathrm{Bu}, \mathrm{H}-\mathrm{Phebox})\left(\mathrm{PEt}_{3}\right)_{2}\right]$ stoichiometry was confirmed by ${ }^{1} \mathrm{H}$ and ${ }^{13} \mathrm{C}\left\{{ }^{1} \mathrm{H}\right\}$ NMR spectroscopy of 7c in benzene- $d_{6}$. Consequently the Phebox ligand in $7 \mathrm{c}$ is $\eta^{1}-C$ bonded to the Ni center and has a structure as proposed in Scheme 3. In this proposed structure, the plane of the aryl ring of the $t$ - $\mathrm{Bu}, \mathrm{H}$-Phebox ligand is perpendicular to the square-planar coordination plane of the $\mathrm{Ni}^{\mathrm{II}}$ center. The metaaryl protons show a diagnostic downfield shift from 6.96 in square-planar complex 2c with an $\eta^{3}$-mer- $N, C, N^{\prime}$-coordinated $t$-Bu,H-Phebox ligand (vide infra) to $7.60 \mathrm{ppm}$ in 7c. The latter value corresponds to the chemical shift for the meta-aryl protons found in the starting $t$-Bu,H-Phebox bromide 5c. Accordingly the formation of $\mathbf{7} \mathbf{a}$ and $\mathbf{7 b}$ in the corresponding reactions could be identified by the shifts of the respective meta-aryl protons in these compounds from 6.98 (2a) to $7.87 \mathrm{ppm}$ for $\mathbf{7 a}$ and 6.98 (2b) to 7.98 for $\mathbf{7 b}$, respectively. In the course of the formation of 2, the $\mathrm{PEt}_{3}$ ligands have to be replaced by bisortho coordination with the imine-N ligands. This feature was observed earlier in the transmetalation reaction of bis-orthoamine chelating aryllithium compounds $\left[\mathrm{Li}\left\{\mathrm{C}_{6} \mathrm{H}_{3}\left(\mathrm{CH}_{2} \mathrm{NR}^{1} \mathrm{R}^{2}\right)-\right.\right.$ $2,6\}]$ with $\left[\mathrm{NiBr}_{2}\left(\mathrm{PEt}_{3}\right)_{2}\right]$, yielding products with and without the phosphine ligands coordinated to the $\mathrm{Ni}^{\mathrm{II}}$ center, depending on the $\mathrm{R}^{1}$ and $\mathrm{R}^{2}$ substituents of the ligand. ${ }^{20} \mathrm{It}$ is not clear yet why $\mathbf{2} \mathbf{b}$ is formed in high yield, whereas in the case of the compound with a $t$-Bu instead of an $i$-Pr group the reaction stops at the stage of the bisphosphine compound 7c.

The alternative route B (Scheme 4) consists of an oxidative addition reaction of the Phebox bromides 5 with $\left[\mathrm{Ni}(\operatorname{cod})_{2}\right]$.

(20) (a) Grove, D. M.; Verschuuren, A. H. M.; van Beek, J. A. M.; van Koten, G. J. Organomet. Chem. 1989, 372, C1. (b) van Beek, J. A. M.; van Koten, G.; Ramp, M. J.; Coenjaarts, N. C.; Grove, D. M.; Goubitz, K.; Zoutberg, M. C.; Stam, C. H.; Smeets, W. J. J.; Spek, A. L. Inorg. Chem. 1991, 30, 3059. 
Scheme 3. Route A: Bis-ortho Lithiation/Transmetalation

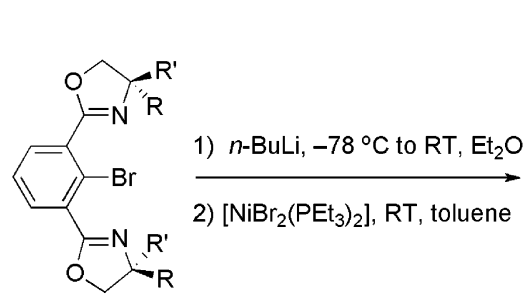

$5 \mathrm{a} R=\mathrm{R}^{\prime}=\mathrm{Me}$

5b $\mathrm{R}=i \operatorname{Pr}, \mathrm{R}^{\prime}=\mathrm{H}$

5c $R=t B u, R^{\prime}=H$

\section{Scheme 4. Route B: Oxidative Addition with $\left[\mathrm{Ni}(\operatorname{cod})_{2}\right]$}

$$
\text { (1) }
$$

$$
\text { 5a) } R=R^{\prime}=M e
$$

5b) $\mathrm{R}=i \mathrm{Pr}, \mathrm{R}^{\prime}=\mathrm{H}$

5c) $R=t B u, R^{\prime}=H$

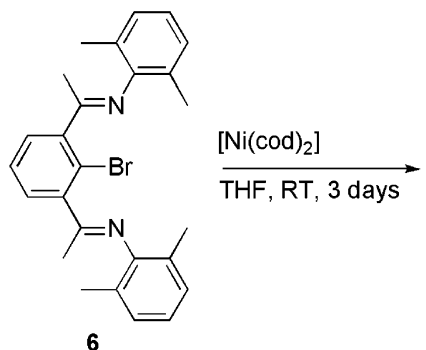

6

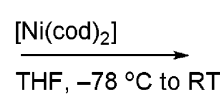

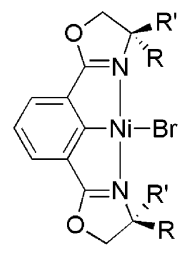

2a) $R=R^{\prime}=\operatorname{Me}(83 \%)$

2b) $\mathrm{R}=\mathrm{iPr}, \mathrm{R}^{\prime}=\mathrm{H}$ (quant.)

2c) $R=t B u, R^{\prime}=H(60 \%)$

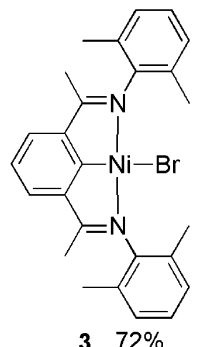

$372 \%$
Because of the absence of potentially coordinating phosphine ligands, formation of complexes of type $\mathbf{7}$ is prevented. Therefore, route $\mathrm{B}$ is a preferred route for the synthesis of $\mathbf{2} \mathbf{a}$ and $\mathbf{2 b}$, and $\mathbf{2 c}$ in particular.

The ketimine-nickel complex $\mathbf{3}$ was prepared by the oxidative addition of $\left[\mathrm{Ni}(\mathrm{cod})_{2}\right]$ with aryl bromide $\mathbf{6}$. The nickel

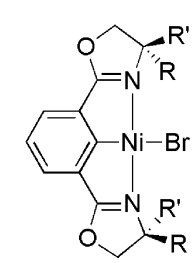

2a $\mathrm{R}=\mathrm{R}^{\prime}=\mathrm{Me}(74 \%)$

2b R $=\mathbb{P P r}, \mathrm{R}^{\prime}=\mathrm{H}(91 \%)$<smiles>[R]C1COC(c2cccc(C3=NC([R])([R])CO3)c2N([PH+]([Z17])Br)[B-](C)(C)Br)=N1</smiles>

$7 \mathrm{a} R=\mathrm{R}^{\prime}=\mathrm{Me}$

$7 \mathrm{~b} \mathrm{R}=\mathrm{iPr}, \mathrm{R}^{\prime}=\mathrm{H}$

7c $R=t B u, R^{\prime}=H(77 \%)$

complexes $\mathbf{2 a}, \mathbf{2 b}$, and $\mathbf{3}$ are stable as solids in air, whereas $\mathbf{2 c}$ decomposes rapidly. In solution all complexes $(\mathbf{2 a}-\mathbf{c}$ and 3) decompose upon exposure to air. Ultimately, the corresponding protonated arene ligand is observed. However, upon addition of a small amount of water to a solution of the Pheboxnickel complexes in benzene- $d_{6}$ under exclusion of oxygen, no decomposition through hydrolysis is observed. This suggests that these nickel complexes are stable toward water but react with oxygen in solution, subsequently followed by hydrolysis.

Structural Features. Single crystals of $\mathbf{2 b}$, suitable for X-ray crystallography, were obtained by vapor diffusion of pentane to a saturated solution in diethyl ether. The top and side-on views of the molecular structure of $\mathbf{2} \mathbf{b}$ are depicted in Figure 3.

The X-ray crystal structure of $\mathbf{3}$ was determined from single crystals, obtained from slow evaporation of a saturated solution in pentane. The molecular structure of $\mathbf{3}$ is depicted in Figure 4.

The structure of $\mathbf{2} \mathbf{b}$ is directly related to the recently published structure of $[\mathrm{NiI}(\mathrm{Me}, \mathrm{Me}-\mathrm{Phebox})]^{5}$ and the analogous Phebox$\mathrm{Pd},{ }^{4 \mathrm{a}, \mathrm{b}, 5}-\mathrm{Pt},{ }^{4 \mathrm{~b}, 7}$ and $-\mathrm{Rh}^{4}$ complexes. The square-planar $\mathrm{Ni}^{\mathrm{II}}$ centers in $\mathbf{2 b}$ and $\mathbf{3}$ are four-coordinate, being bonded to $\mathrm{C}_{i p s o}$ of the aryl ring, the two trans-positioned oxazolinyl-N or imine-N ligands, and a bromide ligand that occupies the fourth coordination site.
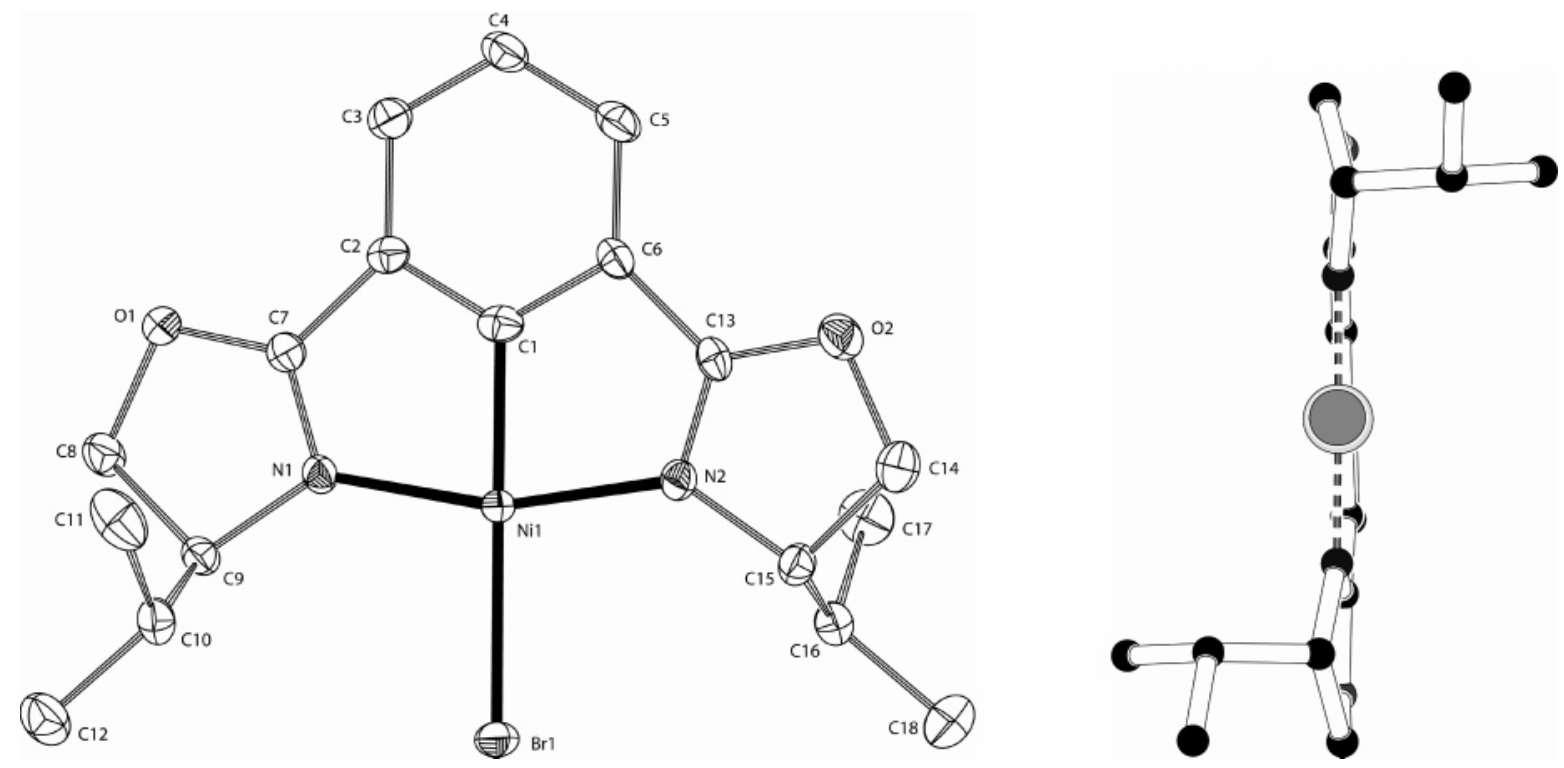

Figure 3. Displacement ellipsoid plot (50\% probability) of [ $\mathrm{NiBr}(i-\mathrm{Pr}, \mathrm{H}-\mathrm{Phebox})](\mathbf{2 b})$ showing full numbering scheme and a side-on view along the $\mathrm{Ni}(1)-\mathrm{C}(1)$ bond. Hydrogen atoms have been omitted for clarity. Selected bond distances $(\AA)$ and angles $(\mathrm{deg})$ : $\mathrm{Ni}(1)-$ $\mathrm{C}(1)$ 1.8491(19), $\mathrm{Ni}(1)-\mathrm{Br}(1)$ 2.3572(4), Ni(1) - N(1) 1.908(2), Ni(1)-N(2) 1.910(2), N(1)-C(7) 1.290(3), N(2)-C(13) 1.286(3), C(1)$\mathrm{Ni}(1)-\mathrm{Br}(1)$ 178.10(6), N(1)-Ni(1)-N(2) 162.20(8), C(1)-Ni(1)-N(1) 81.08(13), C(1)-Ni(1)-N(2) 81.15(13), Br(1)-Ni(1)-N(1) 99.86(6), $\mathrm{Br}(1)-\mathrm{Ni}(1)-\mathrm{N}(2) 97.93(6)$. 

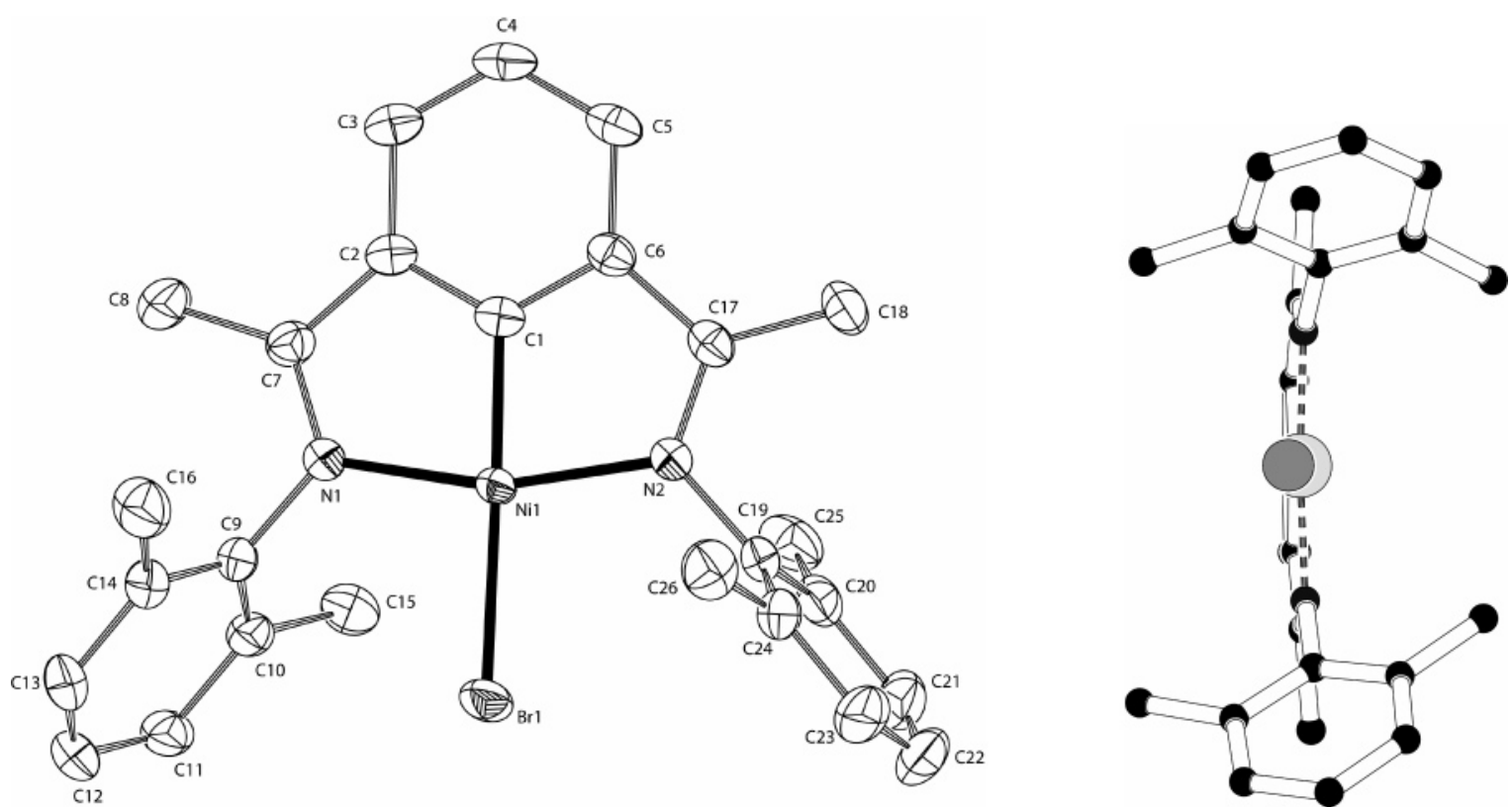

Figure 4. Displacement ellipsoid plot (50\% probability) of $\mathbf{3}$, showing full numbering scheme and a view onto the $\mathrm{N}-\mathrm{Ni}-\mathrm{N}$ moiety along the $\mathrm{Ni}(1)-\mathrm{C}(1)$ bond. Hydrogen atoms have been omitted for clarity. Selected bond distances ( $\mathrm{\AA}$ ), angles (deg), and torsion angles (deg): $\mathrm{Ni}(1)-\mathrm{C}(1)$ 1.819(2), Ni(1)- $\mathrm{Br}(1)$ 2.3419(3), Ni(1)-N(1) 1.9394(19), Ni(1)-N(2) 1.9318(19), N(1)-C(7) 1.307(3), N(1)-C(9) 1.435(3), $\mathrm{N}(2)-\mathrm{C}(17) 1.311(3), \mathrm{N}(2)-\mathrm{C}(19) 1.439(3), \mathrm{C}(1)-\mathrm{Ni}(1)-\mathrm{Br}(1) 174.63(7), \mathrm{N}(1)-\mathrm{Ni}(1)-\mathrm{N}(2) 162.06(8), \mathrm{C}(1)-\mathrm{Ni}(1)-\mathrm{N}(1) 81.26(9), \mathrm{C}(1)-$ $\mathrm{Ni}(1)-\mathrm{N}(2)$ 81.27(9), Br(1)-Ni(1)-N(1) 98.75(6), Br(1)-Ni(1)-N(2) 99.03(6), C(7)-N(1)-C(9) 120.4(2), C(17)-N(2)-C(19) 119.25(19), $\mathrm{Ni}(1)-\mathrm{N}(1)-\mathrm{C}(9)-\mathrm{C}(10)-72.9(3), \mathrm{Ni}(1)-\mathrm{N}(2)-\mathrm{C}(19)-\mathrm{C}(20)$ 89.2(2), $\mathrm{Br}(1)-\mathrm{Ni}(1)-\mathrm{N}(1)-\mathrm{C}(9)-7.96(18), \mathrm{Br}(1)-\mathrm{Ni}(1)-\mathrm{N}(2)-$ C(19) 13.54(18).

The overall geometry of $\mathbf{2 b}$ corresponds well to that of [NiI(Me,Me-Phebox) $]^{5}$

The $\mathrm{N}(1)-\mathrm{Ni}(1)-\mathrm{N}(2)$ angles of $\mathbf{2 b}$ and $\mathbf{3}$ are $162.20(8)^{\circ}$ and $162.06(8)^{\circ}$, respectively. This acute angle reflects the distortion from the square-planar geometry around $\mathrm{Ni}$, which is a common structural feature found in $\eta^{3}$-mer- $N, C, N^{\prime}$ pincer nickel(II) complexes $\left(163.2-168.59^{\circ}\right) .{ }^{12 \mathrm{a}, 20 \mathrm{~b}, 21}$

The degree of planarity of the Phebox ligand skeleton $(\mathrm{C}=\mathrm{N}$ substituent and aryl ring) is illustrated by the side-on views depicted in Figures 3 and 4. The largest deviation from the least-squares planes of the two five-membered rings forming

(21) (a) Kleij, A. W.; Kleijn, H.; Jastrzebski, J. T. B. H.; Spek, A. L.; van Koten, G. Organometallics 1999, 18, 277. (b) Kleijn, H.; Jastrzebski, J. T. B. H.; Gossage, R. A.; Kooijman, H.; Spek, A. L.; van Koten, G. Tetrahedron 1998, 54, 1145. (c) Schimmelpfennig, U.; Zimmering, R.; Schleinitz, K. D.; Stösser, R.; Wenschuh, E.; Baumeister, U.; Hartung, H. Z. Anorg. Allg. Chem. 1993, 619, 1931. (d) Grove, D. M.; van Koten, G.; Ubbels, H. J. C.; Zoet, R.; Spek, A. L. J. Organomet. Chem. 1984, 263, C10.

(22) (a) Mills, A. M.; van Beek, J. A. M.; van Koten, G.; Spek, A. L. Acta Crystallogr., Sect. C 2002, 58, m304. (b) Grove, D. M.; van Koten, G.; Ubbels, H. J. C.; Spek, A. L. J. Am. Chem. Soc. 1982, 104, 4285. (c) Tsubomura, T.; Tanihata, T.; Yamakawa, T.; Ohmi, R.; Tamane, T.; Higuchi, A.; Katoh, A.; Sakai, K. Organometallics 2001, 20, 3833. (d) Rodríguez, G.; Lutz, M.; Spek, A. L.; van Koten, G. Chem.-Eur. J. 2002, 8, 45. (e) Alsters, P. L.; Baesjou, P. J.; Janssen, M. D.; Kooijman, H.; SichererRoetman, A.; Spek, A. L.; van Koten, G. Organometallics 1992, 11, 4124 (f) Dijkstra, H. P.; Slagt, M. Q.; McDonald, A.; Kruithof, C. A.; Kreiter, R.; Mills, A. M.; Lutz, M.; Spek, A. L.; Klopper, W.; van Klink, G. P. M.; van Koten, G. Eur. J. Inorg. Chem. 2003, 830. (g) Steenwinkel, P.; James, S. L.; Grove, D. M.; Kooijman, H.; Spek, A. L.; van Koten, G. Organometallics 1997, 16, 513. (h) Lagunas, M.-C.; Gossage, R. A.; Spek, A. L.; van Koten, G. Organometallics 1998, 17, 731. (i) Slagt, M. Q.; Dijkstra, H. P.; McDonald, A.; Klein Gebbink, R. J. M.; Lutz, M.; Ellis, D. D.; Mills, A. M.; Spek, A. L.; van Koten, G. Organometallics 2003, 22 , 27. (j) Dijkstra, H. P.; Meijer, M. D.; Patel, J.; Kreiter, R.; van Klink, G. P. M.; Lutz, M.; Spek, A. L.; Canty, A. J.; van Koten, G. Organometallics 2001, 20, 3159. (k) Hartshorn, C. M.; Steel, P. J. Organometallics 1998 17, 3487. (1) Canty, A. J.; Patel, J.; Skelton, B. W.; White, A. H. J. Organomet. Chem. 2000, 607, 194. (m) Diez-Barra, E.; Guerra, J.; LopezSolera, I.; Merino, S.; Rodriguez-Lopez, J.; Sanchez-Verdu, P.; Tejeda, J. Organometallics 2003, 22, 541 . the $\eta^{3}$-mer-N,C,N' chelate amounts to $0.012(3) \AA$ for $\mathbf{2} \mathbf{b}$ and $0.020(2) \AA$ for 3 . The angles between these two planes are 1.61$(12)^{\circ}$ and $3.45(10)^{\circ}$, respectively. In 3 , the ortho-xylyl $\mathrm{N}$ substituents bend slightly to one side of the planar ketiminearyl skeleton, while the bromide is bending to the opposite side. This structural feature is illustrated by the torsion angles of $\operatorname{Br}(1)-$ $\mathrm{Ni}(1)-\mathrm{N}(1)-\mathrm{C}(9)$ and $\mathrm{Br}(1)-\mathrm{Ni}(1)-\mathrm{N}(2)-\mathrm{C}(19)$ of $-7.96-$ $(18)^{\circ}$ and $13.54(18)^{\circ}$, respectively, and the $\mathrm{C}(1)-\mathrm{Ni}(1)-\mathrm{Br}(1)$ angle of $174.63(7)^{\circ}$.

The bond lengths about the Ni centers in $\mathbf{2 b}$ and $\mathbf{3}$ follow the general trend as expected $(\mathrm{Ni}<\mathrm{Pd} \sim \mathrm{Pt})$ when comparing the Phebox $-\mathrm{Pd}$ and $-\mathrm{Pt}(\mathbf{B}$, Figure 1$)$ and $\mathrm{NCN}-\mathrm{Ni},-\mathrm{Pd}$, and $-\mathrm{Pt}$ (A, Figure 1) and bis(aldimine)phenyl-Pd and $-\mathrm{Pt}(\mathbf{C}$, Figure 1) bond lengths (Table 1).

(23) (a) Albrecht, M.; James, S. L.; Veldman, N.; Spek, A. L.; van Koten, G. Can. J. Chem. 2001, 79, 709. (b) Terheijden, J.; van Koten, G.; Vinke, I. C.; Spek, A. L. J. Am. Chem. Soc. 1985, 107, 2891. (c) Smeets, W. J. J.; Spek, A. L.; Duisenberg, A. J. M.; van Beek, J. A. M.; van Koten, G. Acta Crystallogr., Sect. C 1987, 43, 463. (d) Terheijden, J.; van Koten, G.; van Beek, J. A. M.; Vriesema, B. K.; Kellogg, R. M.; Zoutberg, M. C.; Stam, C. H. Organometallics 1987, 6, 89. (e) Steenwinkel, P.; Kooijman, H.; Smeets, W. J. J.; Spek, A. L.; Grove, D. M.; van Koten, G. Organometallics 1998, 17, 5411. (f) Back, S.; Albrecht, M.; Spek, A. L.; Rheinwald, G.; Lang, H.; van Koten, G. Organometallics 2001, 20, 1024. (g) Albrecht, M.; Lutz, M.; Schreurs, A. M. M.; Lutz, E. T. H.; Spek, A. L.; van Koten, G. J. Chem. Soc., Dalton Trans. 2000, 3797. (h) Dijkstra, H. P.; Chuchuryukin, A.; Suijkerbuijk, B. M. J. M.; van Klink, G. P. M.; Mills, A. M.; Spek, A. L.; van Koten, G. Adv. Synth. Catal. 2002, 344, 771. (i) Suijkerbuijk, B. M. J. M.; Slagt, M. Q.; Klein Gebbink, R. J. M.; Lutz, M.; Spek, A. L.; van Koten, G. Tetrahedron Lett. 2002, 43, 6565. (j) Albrecht, M.; Gossage, R. A.; Lutz, M.; Spek, A. L.; van Koten, G. Chem.-Eur. J. 2000, 6, 1431. (k) Jude, H.; Bauer, J. A. K.; Connick, W. B. Inorg. Chem. 2002, 41, 2275. (1) Slagt, M. Q.; Klein Gebbink, R. J. M.; Lutz, M.; Spek, A. L.; van Koten, G. J. Chem. Soc., Dalton Trans. 2002, 2591. (m) James, S. I.; Verspui, G.; Spek, A. L.; van Koten, G. Chem. Commun. 1996, 1309. (n) Davies, P. J.; Veldman, N.; Grove, D. M.; Spek, A. L.; Lutz, B. T. G.; van Koten, G. Angew. Chem., Int. Ed. Engl. 1996, 35, 1959. (o) Albrecht, M.; Kocks, B. M.; Spek, A. L.; van Koten, G. J. Organomet. Chem. 2001, 624, 271. (p) van Beek, J. A. M.; van Koten, G.; Dekker, G. P. C. N.; Wissing, E.; Zoutberg, M. C.; Stam, C. H. J. Organomet. Chem. 1990, 394,659 . 
Catalysis and Redox Properties. The catalytic properties of Phebox-Ni complexes $\mathbf{2 a}-\mathbf{c}$ were investigated by testing their catalytic activity in both the radical polymerization reaction of MMA and the Kharasch addition reaction of $\mathrm{CCl}_{4}$ to MMA. It appeared that all these nickel complexes were inactive as catalysts in these types of reactions. This is in concert with the observation that the complexes were stable in the presence of oxidating agents such as $\mathrm{CCl}_{4}$, which excludes the possibility that the persistent "radical" $\mathrm{d}^{7}-\mathrm{Ni}^{\mathrm{III}}$ compound was irreversibly formed. This would block catalysis, as the occurrence of a fast electron-transfer back step is a crucial condition for the re-formation of the $\mathrm{d}^{8}-\mathrm{Ni}^{\mathrm{II}}$ catalyst. ${ }^{12 \mathrm{~d}}$

These observations prompted us to investigate the redox properties of the Phebox - and ketimine- $\mathrm{Ni}^{\mathrm{iI}}$ complexes $\mathbf{2 a}-\mathbf{c}$ and $\mathbf{3}$ and compare them to $[\mathrm{NiBr}(\mathrm{NCN})](\mathbf{1})$, which is a highly effective catalyst. ${ }^{12,13}$ Cyclovoltammetric (CV) experiments with 2a, 2c, and $\mathbf{3}$ were performed in distilled acetone using $(n-\mathrm{Bu})_{4} \mathrm{NBr}$ as supporting electrolyte in the -1.00 to $+1.50 \mathrm{~V}$ region. The potentials are given against the $\mathrm{Ag} / \mathrm{AgCl}$ reference electrode. For comparison, CV experiments were also performed on the $[\mathrm{NiBr}(\mathrm{NCN})]$ complex. The latter complex shows two distinct electron-transfer processes, which are coupled to chemical reactions (transfer of bromide) in the specified experimental region (eqs 1 and 2). ${ }^{25}$

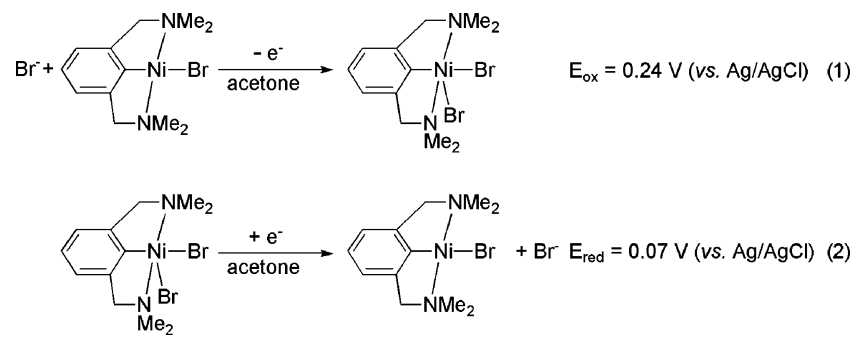

Experiments with 2a, $\mathbf{2 c}$, and $\mathbf{3}$ showed no electrochemical waves in the region where chemical reversible transformations of aryl $-\mathrm{Ni}^{\mathrm{II}}$ to aryl- $\mathrm{Ni} \mathrm{i}^{\mathrm{III}}$ complexes usually occur. This illustrates that Phebox-Ni and bis(ketimine)phenyl-Ni complexes are much more difficult to oxidize as compared to the $[\mathrm{NiBr}(\mathrm{NCN})]$ complex.

Theoretical calculations on existing nickel(II) complexes 1, 2a, and $\mathbf{3}$ were performed to gain insight in the electronic structure of these complexes. All geometries were characterized as real minima by means of a numerical force constant

(24) (a) Donkervoort, J. G.; Vicario, J. L.; Jastrzebski, J. T. B. H.; Smeets, W. J. J.; Spek, A. L.; van Koten, G. J. Organomet. Chem. 1998, 551, 1. (b) Maassarani, F.; Davidson, M. F.; Wehman-Ooyevaar, I. C. M.; Grove, D. M.; van Koten, M. A.; Smeets, W. J. J.; Spek, A. L.; van Koten, G. Inorg. Chim. Acta 1995, 235, 327. (c) Schmulling, M.; Grove, D. M.; van Koten, G.; van Eldik, R.; Veldman, N.; Spek, A. L. Organometallics 1996, 15, 1384. (d) van der Ploeg, A. F. M. J.; van Koten, G.; Vrieze, K.; Spek, A. L.; Duisenberg, A. J. M. Organometallics 1982, 1, 1066. (e) Gossage, R. A.; Ryabov, A. D.; Spek, A. L.; Stufkens, D. J.; van Beek, J. A. M.; van Eldik, R.; van Koten, G. J. Am. Chem. Soc. 1999, 121, 2488. (f) Grove, D. M.; van Koten, G.; Ubbels, H. J. C.; Vrieze, K.; Niemann, L. C.; Stam, C. H. J. Chem. Soc., Dalton Trans. 1986, 717. (g) Terheijden, J.; van Koten, G.; Mul, W. P.; Stufkens, D. J.; Muller, F.; Stam, C. H. Organometallics 1986, 5, 519. (h) van Beek, J. A. M.; van Koten, G.; Smeets, W. J. J.; Spek, A. L. J. Am. Chem. Soc. 1986, 108, 5010. (i) Mayboroda, A.; Comba, P.; Pritzkow, H.; Rheinwald, G.; Lang, H.; van Koten, G. Eur. J. Inorg. Chem. 2003, 1703. (j) Canty, A. J.; Patel, J.; Skelton, B. W.; White, A. H. J. Organomet. Chem. 2000, 599, 195. (k) Albrecht, M.; Gossage, R. A.; Spek, A. L.; van Koten, G. Chem. Commun. 1998, 1003. (1) Chuchuryukin, A. V.; Dijkstra, H. P.; Suijkerbuijk, B. M. J. M.; Klein Gebbink, R. J. M.; van Klink, G. P. M.; Mills, A. M.; Spek, A. L.; van Koten, G. Angew. Chem., Int. Ed. 2003, 42, 228.

(25) Grove, D. M.; van Koten, G.; Mul, P.; Zoet, R.; van der Linden, J. G. M.; Legters, J.; Schmitz, J. E. J.; Murrall, N. W.; Welch, A. J. Inorg. Chem. 1988, 27, 2466.
Table 1. Comparison of Selected Crystallographic Data of Phebox-M MII $^{\mathrm{II}} \mathrm{NCN}-\mathrm{M}^{\mathrm{II}}$, and Bis(aldimine)phenyl-M $\mathrm{M}^{\mathrm{II}}$ Complexes

\begin{tabular}{|c|c|c|}
\hline & $\mathrm{C}_{i p s o}-\mathrm{M}(\AA)$ & $\mathrm{N}-\mathrm{M}(\AA)$ \\
\hline bis(ketimine) $\mathrm{Ph}-\mathrm{Ni}(\mathbf{3})$ & $1.819(2)$ & $1.9318(19), 1.9394(19)$ \\
\hline$i \mathrm{Pr}, \mathrm{H}-\mathrm{Phebox}-\mathrm{Ni}(\mathbf{2 b})$ & $1.8491(19)$ & $1.908(2), 1.910(2)$ \\
\hline Me,Me-Phebox-Ni & $1.857-1.859$ & $1.968-1.977$ \\
\hline $\mathrm{R}, \mathrm{R}^{\prime}-\mathrm{Phebox}-\mathrm{Pd}^{4 \mathrm{a}, \mathrm{b}, 5}$ & $1.845-1.956$ & $2.056-2.072$ \\
\hline $\mathrm{R}, \mathrm{R}^{\prime}-\mathrm{Phebox}-\mathrm{Pt}^{4 \mathrm{~b}, 7}$ & $1.892-1.963$ & $2.026-2.066$ \\
\hline bis(aldimine) $\mathrm{Ph}-\mathrm{Pt}^{8 \mathrm{aa}, \mathrm{c}, \mathrm{e}}$ & $1.889-1.945$ & $2.036-2.097$ \\
\hline bis(aldimine) $\mathrm{Ph}-\mathrm{Pd}^{8 \mathrm{~d}}$ & $1.905-1.918$ & $2.087-2.143$ \\
\hline $\mathrm{NCN}-\mathrm{Ni}^{12 \mathrm{a}, 20 \mathrm{~b}, 21}$ & $1.788-1.899$ & $1.971-2.208$ \\
\hline $\mathrm{NCN}-\mathrm{Pd}^{22}$ & $1.900-2.017$ & $2.007-2.136$ \\
\hline $\mathrm{NCN}-\mathrm{Pt}^{14,22 i, 45,46}$ & $1.901-2.025$ & $2.036-2.168$ \\
\hline
\end{tabular}

Table 2. Calculated ${ } P_{1}$ 's for $1,2 a$, and 3

\begin{tabular}{lccc}
\hline & $\mathbf{1}$ & $\mathbf{2 a}$ & $\mathbf{3}$ \\
\hline${\text { total energy }\left(E_{\mathrm{h}}\right)}$ & -760.6755751 & -1063.5225188 & -1298.9355291 \\
$\mathrm{IP}_{1}(\mathrm{eV}){ }^{a}$ eq 3 & 6.95 & 7.33 & 6.92 \\
$\mathrm{IP}_{1}(\mathrm{eV}),{ }^{b}$ eq 4a & 1.45 & 1.87 & 1.90 \\
$\mathrm{IP}_{1}(\mathrm{eV}),{ }^{c}$ eq 4b & 2.19 & 2.52 & 2.53 \\
$\mathrm{IP}_{1}(\mathrm{eV}),{ }^{d}$ eq 5 & 5.69 & 6.13 & 6.01
\end{tabular}

${ }^{a}$ Ionization potential, calculated as $E_{[\mathrm{NiBr}]^{+}}-E_{[\mathrm{NiBr}]^{*}}{ }^{b}$ Ionization potential, calculated as $E_{[\mathrm{NiBr} 2]^{*}}-\left\{E_{[\mathrm{NiBr}]}+E_{[\mathrm{Br}]^{-}}\right\} .{ }^{c}$ Ionization potential, calculated as $E_{[\mathrm{NiBr} 2]^{*}}-E_{[\mathrm{NiBr} 2]^{-}}{ }^{d}$ Ionization potential, calculated as $E_{[\mathrm{NiBr}(\mathrm{ac} .)]^{+}}-\left\{E_{[\mathrm{NiBr}]}+E_{[\text {ac. }]}\right\}$.

calculation. The calculated geometries of $\mathbf{1}, \mathbf{2} \mathbf{a}$, and $\mathbf{3}$ are in reasonable agreement with those obtained from X-ray crystallography data. ${ }^{26-28}$ Only the $\mathrm{Ni}-\mathrm{Br}$ bond length is systematically overestimated by about $0.1 \AA$ in the calculations.

Equations 3, 4, and 5 schematically represent the processes for which theoretical calculations were performed regarding the ionization potential of the $\mathrm{Ni}^{\mathrm{II}}$ complexes. The calculated energies for the first ionization potential $\left(\mathrm{IP}_{1}\right)$ for the depicted processes starting from the three $\mathrm{d}^{8}-\mathrm{Ni}^{\mathrm{II}}$ complexes $[\mathrm{NiBr}(\mathrm{NCN})]$ (1), [NiBr(Me,Me-Phebox)] (2a), and [NiBr(bis(ketimine)phenyl)] (3) are depicted in Table 2.

(3)

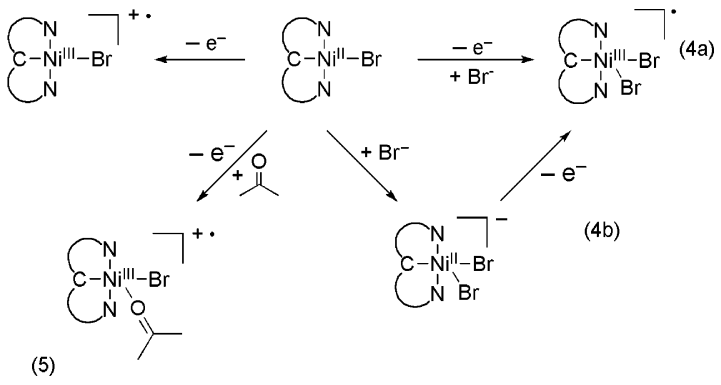

The calculated ionization potentials for the electron-transfer reactions of $\mathrm{d}^{8}-\mathrm{Ni}^{\mathrm{II}}$ to $\mathrm{d}^{7}-\mathrm{Ni}^{\mathrm{III}}$ complexes $\left(\mathrm{IP}_{1}\right.$, eq 3 , Table 2 ) show that for $\mathbf{2 a}$ a higher oxidation potential is expected compared to $\mathbf{1}$ ( 7.33 vs $6.95 \mathrm{eV})$. However, according to these

(26) Comparison of the calculated geometrical features of $[\mathrm{NiBr}(\mathrm{NCN})]$ and experimental ${ }^{21 \mathrm{c}}$ geometrical features of $\left[\mathrm{NiBr}\left(\mathrm{C}_{6} \mathrm{H}_{3}\left(\mathrm{CH}_{2} \mathrm{NEt}_{2}\right)_{2}-2,6\right)\right]$ (distances in $\AA$, angles in deg) calcd (expt): $\mathrm{Ni}(1)-\mathrm{Br}(1) 2.501$ (2.420(1)), $\mathrm{Ni}(1)-\mathrm{N}(1) 2.028$ (2.002(5)), Ni(1)-N(2) 2.028 (2.006(4)), C(1)$\mathrm{Ni}(1) 1.854(1.825(5)), \mathrm{C}(1)-\mathrm{Ni}(1)-\mathrm{N}(1) 83.67(84.5(2)), \mathrm{C}(1)-\mathrm{Ni}(1)-$ $\mathrm{N}(2) 83.61$ (84.2(2)), C(1)-Ni(1)- $\mathrm{Br}(1) 179.99$ (176.6(2)), N(1)-Ni(1)$\mathrm{N}(2) 167.27(168.6(2)), \mathrm{N}(1)-\mathrm{Ni}(1)-\mathrm{Br}(1) 96.33$ (95.6(1)), N(2)-Ni(1)$\operatorname{Br}(1) 96.40(95.8(1))$.

(27) Comparison of the calculated geometrical features of $[\mathrm{NiBr}$ (Me,Me-Phebox)] (2a) and experimental ${ }^{5}$ geometrical features of [NiI(Me,Me-Phebox)] (distances in $\AA$, angles in deg) calcd (expt): $\mathrm{Ni}(1)-$ $\mathrm{Br}(1) 2.472(\mathrm{Ni}(1)-\mathrm{I}(1) 2.5804(5)), \mathrm{Ni}(1)-\mathrm{N}(1) 1.978$ (1.972(3)), Ni(1)$\mathrm{N}(2) 1.978$ (1.977(3)), C(1)-Ni(1) 1.874 (1.859(4)), C(1)-Ni(1)-N(1) 81.06 (80.53(15)), C(1)-Ni(1)-N(2) 81.05 (80.73(15)), C(1)-Ni(1)$\mathrm{Br}(1) 179.95(\mathrm{C}(1)-\mathrm{Ni}(1)-\mathrm{I}(1) \quad 172.61(11)), \mathrm{N}(1)-\mathrm{Ni}(1)-\mathrm{N}(2) 162.12$ (161.04(13)). 


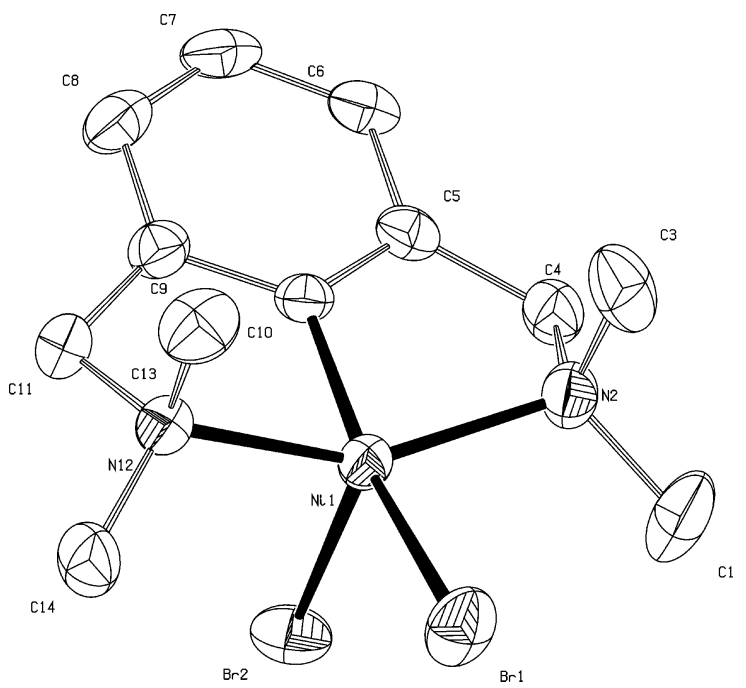

Figure 5. Displacement ellipsoid plot (50\% probability) of $\mathbf{8}$, showing full numbering scheme. Hydrogen atoms have been omitted for clarity. Selected bond distances $(\AA)$ and angles (deg): $\mathrm{Ni}(1)-$ $\mathrm{C}(10)$ 1.894(3), Ni(1)-Br(1) 2.4373(6), Ni(1)-Br(2) 2.4272(6), Ni(1) $-\mathrm{N}(12) 2.041(2), \mathrm{Ni}(1)-\mathrm{N}(2) 2.036(3), \mathrm{C}(10)-\mathrm{Ni}(1)-\mathrm{Br}(1)$ 166.19(9), C(10)-Ni(1)- $\mathrm{Br}(2)$ 90.85(9), N(12)-Ni(1)-N(2) 152.58(10), $\mathrm{C}(10)-\mathrm{Ni}(1)-\mathrm{N}(12) 82.15(11), \mathrm{C}(10)-\mathrm{Ni}(1)-\mathrm{N}(2) 81.50-$ (11), $\mathrm{Br}(1)-\mathrm{Ni}(1)-\mathrm{N}(12)$ 95.37(7), $\mathrm{Br}(2)-\mathrm{Ni}(1)-\mathrm{N}(12)$ 100.25(8), $\mathrm{Br}(1)-\mathrm{Ni}(1)-\mathrm{N}(2)$ 95.29(8), $\mathrm{Br}(2)-\mathrm{Ni}(1)-\mathrm{N}(2)$ 101.85(8), $\mathrm{Br}(1)-$ $\mathrm{Ni}(1)-\mathrm{Br}(2) 102.96(2)$.

calculations, complex $\mathbf{3}$ should be as easy to oxidize as $\mathbf{1}(6.92$ vs $6.95 \mathrm{eV}$ ), which is not in accordance with the cyclovoltammetric experiments. As stipulated in ref 25, the counterion $\left(\mathrm{Br}^{-}\right)$plays an essential role in the cyclic voltammetric experiments (eqs 1,2$)$. In this process (eq $4 \mathrm{a})$ [ $\left.\mathrm{NiBr}_{2}(\mathrm{NCN})\right]$ (8) is formed. Therefore, the reaction energies for reaction $4 \mathrm{a}$ are better measures for the ionization potential observed in the $\mathrm{CV}$ experiments than the $\mathrm{IP}_{1}$ 's calculated for eq 3 . Hence, the energies $\left(\mathrm{IP}_{1}\right)$ for the electron transfer and subsequent reaction with $\mathrm{Br}^{-}$(eq 4a) were calculated for $\mathbf{1}, \mathbf{2} \mathbf{a}$, and $\mathbf{3}$. The calculated geometry of $\mathbf{8}$ is in reasonable agreement with the geometry obtained from an X-ray crystal structure determination. ${ }^{29}$ The molecular structure of $\mathbf{8}$ (depicted in Figure 5; single crystals were obtained from slow evaporation of a saturated solution of 8 in xylene, $\mathrm{RT}^{25}$ ) is directly related to the molecular structure of $\left[\mathrm{NiI}_{2}(\mathrm{NCN})\right]^{30}$ and shows the same geometrical features: a square-pyramidal geometry with the Ni atom displaced ca. 0.34 $\AA$ out of the basal plane ${ }^{31}$ toward the apical atom $\operatorname{Br}(2)$ and a distortion from an ideal square-pyramidal geometry toward trigonal bipyramidal $(\mathrm{C}(10)$ and $\operatorname{Br}(1)$ axial). A very similar crystal structure was also found for the corresponding iron(III) complex $\left[\mathrm{FeCl}_{2}(\mathrm{NCN})\right] .{ }^{32}$

The energies $\left(\mathrm{IP}_{1}\right)$ for this electron transfer and subsequent reaction with $\mathrm{Br}^{-}$(eq 4a) were calculated as the difference

(28) Comparison of the calculated and experimental geometrical features of [NiBr(bis(ketimine)phenyl)] (3) (distances in $\AA$, angles in deg) calcd (expt): $\mathrm{Ni}(1)-\mathrm{Br}(1) 2.429$ (2.3419(3)), Ni(1)-N(1) 1.985 (1.9394(19)), $\mathrm{Ni}(1)-\mathrm{N}(2) 1.985$ (1.9318(19)), C(1)-Ni(1) 1.838 (1.819(2)), C(1)-Ni(1) $-\mathrm{N}(1) 81.40(81.26(9)), \mathrm{C}(1)-\mathrm{Ni}(1)-\mathrm{N}(2) 81.40(81.27(9)), \mathrm{C}(1)-\mathrm{Ni}-$ (1) $-\mathrm{Br} 180.00(174.63(7)), \mathrm{N}(1)-\mathrm{Ni}-\mathrm{N}(2) 162.80(162.06(8)), \mathrm{N}(1)-\mathrm{Ni}-$ Br 98.60 (98.75(6)), N(2)-Ni-Br 98.60 (99.03(6)).

(29) Comparison of the calculated and experimental geometrical features of $\left[\mathrm{NiBr}_{2}(\mathrm{NCN})\right](\mathbf{8})$ (distances in $\AA$, angles in deg) calc (expt): $\mathrm{Ni}(1)-$ $\mathrm{Br}(1) 2.516$ (2.4373(6)), Ni(1)-Br(2) 2.526 (2.4272(6)), Ni(1)-N(12) 2.087 (2.041(2)), C(10)-Ni(1) 1.893 (1.894(3)), C(10)-Ni(1)-N(12) 82.79 (82.15(11)), C(10)-Ni(1)-N(2) 82.86 (81.50(11)), C(10)-Ni(1)- Br(1) 162.00 (166.19(9)), C(10)-Ni(1)-Br(2) 87.99 (90.85(9)), N(12)-Ni(1)$\mathrm{N}(2) 157.50(152.58(10)), \mathrm{N}(12)-\mathrm{Ni}(1)-\mathrm{Br}(1) 94.16(95.37(7)), \mathrm{N}(12)-$ $\mathrm{Ni}(1)-\mathrm{Br}(2) 98.35$ (100.25(8)), $\mathrm{Br}(1)-\mathrm{Ni}(1)-\mathrm{Br}(2) 110.02$ (102.96(2)). between the total energies of, for example, $\mathbf{8}$ and the sum of $\mathbf{1}$ and $\mathrm{Br}^{-}$. The ionization potentials thus calculated $(1.45,1.87$, and $1.90 \mathrm{eV}$, respectively, Table 2) show that for $\mathbf{2 a}$ and $\mathbf{3}$ a similar oxidation potential is expected, while for $\mathbf{1}$ a significantly lower energy is calculated, rationalizing the observed wave in the $\mathrm{CV}$ experiments for $\mathbf{1}$ and the absence of a wave for $\mathbf{2} \mathbf{a}$ and 3 (in the region between -1.00 and $+1.50 \mathrm{~V}$ ). ${ }^{33}$ However, in this calculation we assume that the $\mathrm{Br}^{-}$anion is not associated with the Ni complex. Assuming that prior to the oxidation reaction the bromide anion interacts with the neutral nickel complex (eq 4b), theoretical calculations confirm that for $\mathbf{1}$ and $\mathbf{2 a}$ this is indeed a plausible mechanism for the oxidation reactions. For 1 and $\mathbf{2 a}$, a $\left[\mathrm{Ni}-\mathrm{Br}_{2}\right]^{-}$complex could be located with a $\mathrm{Ni}-\mathrm{Br}^{-}$distance of 3.283 and $2.998 \AA$, respectively, but for $3-\mathrm{Br}^{-}$the $\mathrm{Ni}-\mathrm{Br}^{-}$distance is already $3.696 \AA$, indicating a very weak interaction with the $\mathrm{Ni}$ atom. The $\mathrm{IP}_{1}$ 's calculated for these processes (eq 4b) lead to similar conclusions to those for the model reactions with $\mathrm{Br}^{-}$at infinite distance (eq 4a).

If instead of a complexing bromide ion, coordination by a solvent molecule (acetone) is taken into account (eq 5), similar results to those for the process described in eq $4 \mathrm{a}$ are obtained (Table 2). This further corroborates the experimental result that the counterion or the solvent is involved in the charge-transfer process $^{25}$ as well as the absence of an electrochemical wave between -1.00 and $+1.50 \mathrm{~V}$ in the cyclovoltammetric experiments with $\mathbf{2} \mathbf{a}$ and $\mathbf{3}$.

In conclusion, synthesis of the Phebox-Ni complexes was accomplished via two different synthetic routes. One route involves the selective bis-ortho lithiation of the corresponding Phebox $-\mathrm{Br}$ followed by transmetalation of the in situ formed Phebox-Li with, for example, $\left[\mathrm{NiBr}_{2}\left(\mathrm{PEt}_{3}\right)_{2}\right]$ (route A). Following route $A$, a side product, characterized as $\left[\mathrm{NiBr}\left(\mathrm{R}, \mathrm{R}^{\prime}\right.\right.$ Phebox $\left.\left(\mathrm{PEt}_{3}\right)_{2}\right]$ (7), was formed. In the case of reaction with the most sterically hindered Phebox ligand 5c $\left(\mathrm{R}=t-\mathrm{Bu}, \mathrm{R}^{\prime}=\right.$ $\mathrm{H})$ 7c was formed exclusively. The second route, $\mathrm{B}$, makes use of an oxidative addition reaction of the aryl bromide with $\left[\mathrm{Ni}(\operatorname{cod})_{2}\right]$. This route leads to the exclusive formation of $\mathbf{2}$ and is also used for the synthesis of [ $\mathrm{NiBr}(\mathrm{bis}$ (ketimine)phenyl)] (3). The molecular structures of $\mathbf{2} \mathbf{b}$ and $\mathbf{3}$ were determined by $\mathrm{X}$-ray crystal structure determination. The Phebox and bis(ketimine)phenyl ligands are $\eta^{3}-m e r-N, C, N^{\prime}$ bonded in these complexes. The terdentate $N, C, N^{\prime}$ ligands in these complexes have planar arrangements of the $\mathrm{C}=\mathrm{N}$ and aryl plane. However, even these rigid ligands can bind in the monodentate $\eta^{1}-C$ bonding mode, as was demonstrated for $[\mathrm{NiBr}(t-\mathrm{Bu}, \mathrm{H}-\mathrm{Phebox})-$ $\left.\left(\mathrm{PEt}_{3}\right)_{2}\right]$ (7c). Complexes 2 are inactive in ATRP and ATRA, which is ascribed to the relatively high oxidation potential of $\mathrm{Ni}^{\mathrm{II}}$-Phebox complexes, which excludes the (reversible) formation of a $\mathrm{d}^{7}-\mathrm{Ni}^{\mathrm{III}}$ complex, a crucial condition for ATRP and ATRA. This was confirmed by cyclic voltammetry measurements with complexes $\mathbf{2 a}, \mathbf{2 c}$, and $\mathbf{3}$ using $(n-\mathrm{Bu})_{4} \mathrm{NBr}$ as electrolyte. Theoretical calculations showed that the energy ( $\left.\mathrm{IP}_{1}\right)$ needed for the oxidation reaction occurring during the $\mathrm{CV}$ experiments is considerably higher for [ $\mathrm{NiBr}(\mathrm{Me}, \mathrm{Me}-\mathrm{Phebox})]$ $(1.87 \mathrm{eV})$ and $[\mathrm{NiBr}($ bis(ketimine)phenyl)] $(1.90 \mathrm{eV})$ than for $[\mathrm{Ni}(\mathrm{NCN}) \mathrm{Br}](1.45 \mathrm{eV})$.

(30) Grove, D. M.; van Koten, G.; Zoet, R. J. Am. Chem. Soc. 1983, 105,1379

(31) Defined by the atoms $\mathrm{C}(10), \mathrm{N}(12), \mathrm{N}(2)$, and $\mathrm{Br}(1)$.

(32) De Koster, A.; Kanters, J. A.; Spek, A. L.; van der Zeijden, A. A. H.; van Koten, G.; Vrieze, K. Acta Crystallogr. 1985, C41, 893.

(33) On the basis of the theoretical calculations, the experimental oxidation wave for [ $\mathrm{NiBr}(\mathrm{Me}, \mathrm{Me}-\mathrm{Phebox})]$ can be approximately expected at about $\mathrm{IP}_{1}([\mathrm{NiBr}(\mathrm{Me}, \mathrm{Me}-\mathrm{Phebox})])-\mathrm{IP}_{1}([\mathrm{NiBr}(\mathrm{NCN})])=0.42 \mathrm{~V}$ higher than $E_{\mathrm{ox}}$ for $[\mathrm{NiBr}(\mathrm{NCN})]$. 


\section{Experimental Section}

Experiments were carried out under a dry, oxygen-free, nitrogen atmosphere, using standard Schlenk techniques. Solvents were dried and distilled from sodium (pentane, toluene), $\mathrm{Na}$ /benzophenone (diethyl ether, tetrahydrofuran), $\mathrm{CaH}_{2}\left(\mathrm{CH}_{2} \mathrm{Cl}_{2}, \mathrm{CH}_{3} \mathrm{CN}\right)$, and $\mathrm{KOH}$ $\left(\mathrm{Et}_{3} \mathrm{~N}\right)$ prior to use. $n$-BuLi (1.6 M in hexanes) was ordered from Acros and used as received. ${ }^{1} \mathrm{H}$ and ${ }^{13} \mathrm{C}\left\{{ }^{1} \mathrm{H}\right\}$ NMR spectra were recorded on a Varian Inova 300 spectrometer; ${ }^{31} \mathrm{P}\left\{{ }^{1} \mathrm{H}\right\}$ NMR experiments, on a Varian Mercury 200 spectrometer. Benzene- $d_{6}$ was purchased from Cambridge Isotope Laboratories, distilled from sodium, and stored in a nitrogen-filled M-Braun glovebox. Other NMR solvents (acetone- $d_{6}, \mathrm{CDCl}_{3}$ ) were used as received. ${ }^{1} \mathrm{H}$ and ${ }^{13} \mathrm{C}\left\{{ }^{1} \mathrm{H}\right\}$ chemical shifts $(\delta)$ are given in ppm relative to the solvent residual signal as an internal standard. ${ }^{31} \mathrm{P}\left\{{ }^{1} \mathrm{H}\right\}$ NMR chemical shifts are referenced externally to $\mathrm{H}_{3} \mathrm{PO}_{4}$. Electrochemical experiments were performed with an Autolab PGSTAT 10 cyclic voltammeter under an argon atmosphere. Acetone, used for cyclovoltammetry experiments, was distilled from $\mathrm{CaCl}_{2}$ under an argon atmosphere prior to use. 2-Bromoisophthalic acid, ${ }^{14}$ L-valinol, and L-tertleucinol ${ }^{34}$ were synthesized according to literature procedures. [R, $\mathrm{R}^{\prime}$ PheboxBr] was synthesized according to a combination of literature procedures. ${ }^{15,16}$ All other chemicals were purchased from either Acros or Aldrich and used as received. Elemental analyses were performed by Kolbe, Mikroanalytisches Laboratorium, Mülheim a.d. Ruhr, Germany. Theoretical calculations were performed at the (U)B3LYP/LANL2-DZ level, ${ }^{35}$ using GAMESS-UK. ${ }^{36}$

Synthesis of [Me,Me-PheboxBr] (5a). Thionyl chloride $(12 \mathrm{~mL}$, $164 \mathrm{mmol}$ ) was added to 2-bromoisophthalic acid (9.8 g, 40.1 mmol). The mixture was refluxed overnight, and the residual $\mathrm{SOCl}_{2}$ was removed in vacuo. Of the resulting 2-bromoisophthalic acid chloride, $6.9 \mathrm{~g}$ ( $24.5 \mathrm{mmol})$ was weighed in a $500 \mathrm{~mL}$ one-necked round-bottom flask, equipped with a nitrogen inlet, and dissolved in $\mathrm{CH}_{2} \mathrm{Cl}_{2}(25 \mathrm{~mL})$. The temperature was cooled to $0{ }^{\circ} \mathrm{C}$. In a separate Schlenk vessel, 2-amino-2-methylpropanol (5.07 g, 56.3 $\mathrm{mmol})$ and triethylamine $(14 \mathrm{~mL}, 100 \mathrm{mmol})$ were dissolved in $\mathrm{CH}_{2} \mathrm{Cl}_{2}$ (35 mL) and slowly added to the cooled 2-bromoisophthalic acid chloride solution. The reaction mixture was warmed to room temperature overnight, after which the solvent was removed in vacuo. Acetonitrile $(200 \mathrm{~mL}), \mathrm{PPh}_{3}(23.7 \mathrm{~g}, 90.6 \mathrm{mmol})$, and triethylamine $(15 \mathrm{~mL}, 108 \mathrm{mmol})$ were added to the residue. The temperature was reduced to $0{ }^{\circ} \mathrm{C}$, after which $\mathrm{CCl}_{4}(21 \mathrm{~mL}, 215$ mmol) was slowly added via syringe. The reaction mixture was warmed to room temperature overnight, after which the mixture was quenched with $\mathrm{H}_{2} \mathrm{O}(10 \mathrm{~mL})$ and the volatiles were removed in vacuo. The residue was dissolved in $\mathrm{H}_{2} \mathrm{O}(200 \mathrm{~mL})$ and ethyl acetate $(200 \mathrm{~mL})$. After separation of the layers, the organic layer was washed with $\mathrm{H}_{2} \mathrm{O}(100 \mathrm{~mL})$. The combined aqueous layers were extracted with ethyl acetate $(3 \times 100 \mathrm{~mL})$. The combined organic layers were dried on $\mathrm{MgSO}_{4}$ and filtered. After the solvent was removed in vacuo, the residue was stirred for $3 \mathrm{~h}$ in diethyl ether $(250 \mathrm{~mL})$. The suspension was filtered, the residue was washed with diethyl ether $(200 \mathrm{~mL})$, and the filtrate was concentrated in vacuo. The crude product was filtered over alumina (neutral Merck

(34) McKennon, M. J.; Meyers, A. I. J. Org. Chem. 1993, 58, 3568.

(35) Basis sets were obtained from the Extensible Computational Chemistry Environment Basis Set Database, Version 02/25/04, as developed and distributed by the Molecular Science Computing Facility, Environmental and Molecular Sciences Laboratory, which is part of the Pacific Northwest Laboratory, P.O. Box 999, Richland, WA 99352, and funded by the U.S. Department of Energy. The Pacific Northwest Laboratory is a multiprogram laboratory operated by Battelle Memorial Institute for the U.S. Departmen of Energy under contract DE-AC06-76RLO 1830. Contact David Feller or Karen Schuchardt for further information. Dunning, T. H., Jr.; Hay, P. J. Methods of Electronic Structure Theory, 2nd ed.; Schaefer, H. F., III, Ed.; Plenum Press: New York, 1977. Hay, P. J.; Wadt, W. R. J. Chem. Phys. 1985, 82, 284. Hay, P. J.; Wadt, W. R. J. Chem. Phys. 1985, 82, 299.

(36) Guest, M. F.; Bush, L. J.; van Dam, H. J.; Sherwood, P.; Thomas, M. J. H.; van Lenthe, J.; Haventih, R. W. A.; Kendrick, J. J. Mol. Phys. 2005, 103, 719 .
$90)$ in diethyl ether $\left(R_{f} 0.25\right)$, resulting in a white solid (6.95 g, $81 \%$ ). IR (neat, $\mathrm{cm}^{-1}$ ): $v_{\max } 2966,1663,1643,1423,1351,1192$, 998, 952, 807, 736. ${ }^{1} \mathrm{H}$ NMR (300 MHz, acetone- $\left.d_{6}\right): \delta 1.35(\mathrm{~s}$, $\left.12 \mathrm{H}, \mathrm{CMe}_{2}\right), 4.14\left(\mathrm{~s}, 4 \mathrm{H}, \mathrm{CH}_{2}\right), 7.52\left(\mathrm{t}, 1 \mathrm{H},{ }^{3} \mathrm{~J}_{\mathrm{H}-\mathrm{H}}=7.7 \mathrm{~Hz}, \mathrm{ArH}\right)$, $7.67\left(\mathrm{~d}, 2 \mathrm{H},{ }^{3} J_{\mathrm{H}-\mathrm{H}}=7.5 \mathrm{~Hz}, \operatorname{ArH}\right) .{ }^{13} \mathrm{C}\left\{{ }^{1} \mathrm{H}\right\} \mathrm{NMR}(75 \mathrm{MHz}$, acetone- $\left.d_{6}\right): \delta 28.4\left(\mathrm{CMe}_{2}\right), 69.1\left(\mathrm{CMe}_{2}\right), 79.9\left(\mathrm{OCH}_{2}\right), 121.7$ ( $\mathrm{ArC}$ ), 128.1 ( $\mathrm{ArC}), 133.2(\mathrm{ArC}), 133.7(\mathrm{ArC}), 161.7(\mathrm{OCN})$. Anal. Calcd for $\mathrm{C}_{16} \mathrm{H}_{19} \mathrm{BrN}_{2} \mathrm{O}_{2}$ : C, 54.71; H, 5.45; N, 7.98. Found: C, 54.63; H, 5.38; N, 7.96.

Synthesis of $\left[(S, S) i\right.$-Pr,H-PheboxBr] $(5 \mathrm{~b}) .{ }^{4 \mathrm{~d}}$ An analogous procedure to the synthesis of $\mathbf{5 a}$ was employed with 2-bromoisophthalic acid $(5.05 \mathrm{~g}, 21 \mathrm{mmol})$ and L-valinol $(4.91 \mathrm{~g}, 48 \mathrm{mmol})$ : light yellow oil $(5.16 \mathrm{~g}, 67 \%), R_{f}$ value (diethyl ether) $0.28,[\alpha]_{\mathrm{D}}{ }^{20}$ -63.2 (c $0.10 \mathrm{~g} / \mathrm{mL}, \mathrm{CH}_{2} \mathrm{Cl}_{2}$ ). IR (neat, $\mathrm{cm}^{-1}$ ): $v_{\max } 2958,1660$, $1362,1123,1069,965,728 .{ }^{1} \mathrm{H}$ NMR $\left(300 \mathrm{MHz}, \mathrm{CDCl}_{3}\right): \delta 0.98$ $\left(\mathrm{d}, 6 \mathrm{H},{ }^{3} J_{\mathrm{H}-\mathrm{H}}=6.6 \mathrm{~Hz}, \mathrm{CHMe}\right), 1.04\left(\mathrm{~d}, 6 \mathrm{H},{ }^{3} J_{\mathrm{H}-\mathrm{H}}=6.6 \mathrm{~Hz}\right.$, $\mathrm{CHMe}$ ), 1.91 (septet, $2 \mathrm{H},{ }^{3} J_{\mathrm{H}-\mathrm{H}}=6.6 \mathrm{~Hz}, \mathrm{CHMe}$ ), $4.18(\mathrm{~m}, 4 \mathrm{H}$, $\left.\mathrm{OCH}_{2}\right), 4.45(\mathrm{~m}, 2 \mathrm{H}, \mathrm{CHN}), 7.37\left(\mathrm{t}, 1 \mathrm{H},{ }^{3} J_{\mathrm{H}-\mathrm{H}}=7.7 \mathrm{~Hz}, \mathrm{Ar} H\right)$, $7.65\left(\mathrm{~d}, 2 \mathrm{H},{ }^{3} J_{\mathrm{H}-\mathrm{H}}=7.8 \mathrm{~Hz}, \mathrm{Ar} H\right) \cdot{ }^{13} \mathrm{C}\left\{{ }^{1} \mathrm{H}\right\} \mathrm{NMR}\left(\mathrm{CDCl}_{3}, 75\right.$ $\mathrm{MHz}): \delta 32.3\left(\mathrm{CMe}_{2}\right), 60.0\left(\mathrm{CMe}_{2}\right), 70.2(\mathrm{CHN}), 72.6\left(\mathrm{OCH}_{2}\right)$, $121.0(\mathrm{ArC}), 126.6(\mathrm{ArC}), 132.0(\mathrm{ArC}), 132.2(\mathrm{ArC}), 162.6(\mathrm{OCN})$. Anal. Calcd for $\mathrm{C}_{18} \mathrm{H}_{23} \mathrm{BrN}_{2} \mathrm{O}_{2}$ : C, 57.00; H, 6.11; N, 7.39. Found: C, 56.88; H, 6.07; N, 7.26.

Synthesis of $[(S, S)$ - $t$-Bu,H-PheboxBr $](5 \mathrm{c}){ }^{6 a}$ An analogous procedure to the synthesis of $\mathbf{5 a}$ was employed with 2-bromoisophthalic acid (4.08 g, $15 \mathrm{mmol})$ and L-tert-leucinol $(3.52 \mathrm{~g}, 30$ mmol): colorless oil (4.31 g, 73\%), $R_{f}$ value (1:1 diethyl ether/ ethyl acetate) $0.71,[\alpha]_{\mathrm{D}}{ }^{20}-60.2(c 0.11 \mathrm{~g} / \mathrm{mL}, \mathrm{EtOH})$. IR (neat, $\left.\mathrm{cm}^{-1}\right): v_{\max } 2954,1663,1362,970 .{ }^{1} \mathrm{H}$ NMR $\left(300 \mathrm{MHz}, \mathrm{CDCl}_{3}\right)$ : $\delta 0.96\left(\mathrm{~s}, 18 \mathrm{H}, \mathrm{CMe}_{3}\right), 4.06\left(\mathrm{dd}, 2 \mathrm{H},{ }^{3} J_{\mathrm{H}-\mathrm{H}}=10.1 \mathrm{~Hz},{ }^{2} J_{\mathrm{H}-\mathrm{H}}=\right.$ $\left.8.3 \mathrm{~Hz}, \mathrm{OCH}_{2}\right), 4.22\left(\mathrm{t}, 2 \mathrm{H},{ }^{3} J_{\mathrm{H}-\mathrm{H}}=8.7 \mathrm{~Hz}, \mathrm{CHN}\right), 4.37(\mathrm{dd}, 2 \mathrm{H}$, $\left.{ }^{3} J_{\mathrm{H}-\mathrm{H}}=10.1 \mathrm{~Hz},{ }^{2} J_{\mathrm{H}-\mathrm{H}}=8.9 \mathrm{~Hz}, \mathrm{OCH}_{2}\right), 7.33\left(\mathrm{t}, 1 \mathrm{H},{ }^{3} J_{\mathrm{H}-\mathrm{H}}=\right.$ $7.7 \mathrm{~Hz}, \operatorname{ArH}), 7.60\left(\mathrm{~d}, 2 \mathrm{H},{ }^{3} J_{\mathrm{H}-\mathrm{H}}=7.2 \mathrm{~Hz}, \operatorname{ArH}\right) .{ }^{13} \mathrm{C}\left\{{ }^{1} \mathrm{H}\right\} \mathrm{NMR}$ $\left(75 \mathrm{MHz}, \mathrm{CDCl}_{3}\right): \delta 26.1\left(\mathrm{CMe}_{3}\right), 34.0\left(\mathrm{CMe}_{3}\right), 69.2(\mathrm{CHN}), 76.7$ $\left(\mathrm{OCH}_{2}\right), 121.4(\mathrm{ArC}), 127.0(\mathrm{ArC}), 132.4(\mathrm{ArC}), 132.6(\mathrm{ArC}), 163.0$ $(C N)$. Anal. Calcd for $\mathrm{C}_{20} \mathrm{H}_{27} \mathrm{BrN}_{2} \mathrm{O}_{2}$ : C, 58.97; H, 6.68; N, 6.88. Found: C, 59.10; H, 6.74; N, 6.76.

Synthesis of 2,6-Bis $[N$-(2',6'-dimethylphenyl)ketimino $]$ phenyl Bromide (6). 2,6-Diacetylphenyl bromide (3.6 g, $15 \mathrm{mmol}$ ), 2,6dimethylaniline $(4.5 \mathrm{~mL}, 36 \mathrm{mmol})$, and $\mathrm{Si}(\mathrm{OEt})_{4}(8 \mathrm{~mL}, 36 \mathrm{mmol})$ were combined in a Schlenk vessel equipped with a still head and treated with 20 drops of $\mathrm{H}_{2} \mathrm{SO}_{4}(95 \%)$. The solution was heated at $160{ }^{\circ} \mathrm{C}$ for $24 \mathrm{~h}$. The distillate $(\mathrm{EtOH})$ was discarded. 2,6Dimethylaniline (1.2 mL, $5.4 \mathrm{mmol}$ ) and 10 drops of $\mathrm{H}_{2} \mathrm{SO}_{4}(95 \%)$ were added, and the mixture was heated for another $24 \mathrm{~h}$ at 160 ${ }^{\circ} \mathrm{C}$. Ethanol $(80 \mathrm{~mL})$ and $\mathrm{KOH}_{\mathrm{aq}}\left(10 \mathrm{~mL}, 2 \mathrm{M}\right.$ solution in $\left.\mathrm{H}_{2} \mathrm{O}\right)$ were added to the reaction mixture at room temperature and stirred for $4 \mathrm{~h}$. The resulting suspension was concentrated in vacuo, diethyl ether was added, and the slurry was filtered. The filtrate was washed with brine and with water, dried on $\mathrm{MgSO}_{4}$, and filtered. The filtrate was dried in vacuo. The residue was submitted to a Kugelrohr distillation at $160{ }^{\circ} \mathrm{C}$ for $30 \mathrm{~min}$. The residue was purified by column chromatography (silica, hexane/EtOAc, 4:1, $R_{f} 0.33$ ): white solid $\left(5.9 \mathrm{~g}, 78 \%\right.$ ). IR (neat, $\mathrm{cm}^{-1}$ ): $v_{\max } 1664,1646,1467,1199$, 793, 758. ${ }^{1} \mathrm{H}$ NMR $\left(300 \mathrm{MHz}, \mathrm{C}_{6} \mathrm{D}_{6}\right): \delta 1.84$ (s, 6H, NCMe), 2.28 $(\mathrm{s}, 12 \mathrm{H}, \operatorname{ArMe}), 7.08-7.11(\mathrm{~m}, 3 \mathrm{H}, \operatorname{Ar} H), 7.13\left(\mathrm{~d}, 4 \mathrm{H},{ }^{3} J_{\mathrm{H}, \mathrm{H}}=\right.$ $15.3 \mathrm{~Hz}, \operatorname{Ar} H), 7.40(\mathrm{~d}, 2 \mathrm{H}, 7.5 \mathrm{~Hz}, \operatorname{Ar} H) .{ }^{13} \mathrm{C}\left\{{ }^{1} \mathrm{H}\right\} \mathrm{NMR}(75 \mathrm{MHz}$, $\left.\mathrm{C}_{6} \mathrm{D}_{6}\right): \delta 18.5(\mathrm{ArMe}), 21.4(\mathrm{NCMe}), 117.9(\mathrm{ArC}), 123.6(\mathrm{ArC})$, 125.7 ( $\mathrm{ArC}), 128.6(\mathrm{ArC}), 129.4(\mathrm{ArC}), 145.0(\mathrm{ArC}), 148.7(\mathrm{ArC})$, $169.2(\mathrm{NCMe})$. Anal. Calcd for $\mathrm{C}_{26} \mathrm{H}_{27} \mathrm{BrN}_{2}$ : C, 69.80; H, 6.08; $\mathrm{N}, 6.26$. Found: C,69.74; H, 6.07; N, 6.24.

Synthesis of [NiBr(Me,Me-Phebox)] (2a) via Route A. $n$-BuLi (1.2 $\mathrm{mL}, 1.92 \mathrm{mmol}, 1.6 \mathrm{M}$ solution in hexanes) was added to a solution of $5 \mathbf{a}(0.60 \mathrm{~g}, 1.71 \mathrm{mmol})$ in toluene $(30 \mathrm{~mL})$ at $-78{ }^{\circ} \mathrm{C}$. After stirring for $3.5 \mathrm{~h}$, the deep purple solution was added cold to a solution of $\left[\mathrm{NiBr}_{2}\left(\mathrm{PEt}_{3}\right)_{2}\right](0.73 \mathrm{~g}, 1.61 \mathrm{mmol})$ in toluene $(30$ $\mathrm{mL}$ ). After stirring for $16 \mathrm{~h}$, the dark brown reaction mixture 
containing a light precipitate was centrifugated and the supernatant was separated. The precipitate was extracted with toluene $(20 \mathrm{~mL})$. The toluene layers were dried in vacuo and washed with hexanes $(2 \times 20 \mathrm{~mL})$, which yielded a bright orange solid $(0.49 \mathrm{~g}$, 74\%). IR (neat, $\mathrm{cm}^{-1}$ ): $v_{\max }$ 2964, 1644, 1645, 1490, 1405, 1131, 981, 796, 783. ${ }^{1} \mathrm{H}$ NMR $\left(\mathrm{C}_{6} \mathrm{D}_{6}, 300 \mathrm{MHz}\right): \delta 1.49(\mathrm{~s}, 12 \mathrm{H}, \mathrm{CMe} 2)$, $3.59\left(\mathrm{~s}, 4 \mathrm{H}, \mathrm{OCH}_{2}\right), 6.69\left(\mathrm{t}, 1 \mathrm{H},{ }^{3} J_{\mathrm{H}-\mathrm{H}}=7.5 \mathrm{~Hz}, \mathrm{Ar} H\right), 6.98(\mathrm{~d}$, $\left.2 \mathrm{H},{ }^{3} \mathrm{~J}_{\mathrm{H}-\mathrm{H}}=7.2 \mathrm{~Hz}, \mathrm{ArH}\right) .{ }^{13} \mathrm{C}\left\{{ }^{1} \mathrm{H}\right\} \mathrm{NMR}\left(\mathrm{C}_{6} \mathrm{D}_{6}, 75 \mathrm{MHz}\right): \delta$ $28.2\left(\mathrm{CMe}_{2}\right), 65.6\left(\mathrm{CMe}_{2}\right), 84.4\left(\mathrm{OCH}_{2}\right), 124.0(\mathrm{ArC}), 124.5(\mathrm{ArC})$, $130.5(\mathrm{ArC}), 168.7(\mathrm{ArC}), 172.0(\mathrm{OCN})$. Anal. Calcd for $\mathrm{C}_{16} \mathrm{H}_{19} \mathrm{BrN}_{2} \mathrm{NiO}_{2}$ : C, 46.88; $\mathrm{H}, 4.67 ; \mathrm{N}, 6.83$. Found: $\mathrm{C}, 47.03$; H, 4.73; N, 6.75 .

Synthesis of $(S, S)$-[NiBr(i-Pr,H-Phebox)] (2b) via Route A. An analogous procedure to the synthesis of $\mathbf{2 a}$ was employed with 5b $(0.60 \mathrm{~g}, 1.58 \mathrm{mmol}), n$-BuLi $(1.1 \mathrm{~mL}, 1.76 \mathrm{mmol}, 1.6 \mathrm{M}$ in hexane), and $\left[\mathrm{NiBr}_{2}\left(\mathrm{PEt}_{3}\right)_{2}\right](0.68 \mathrm{~g}, 1.45 \mathrm{mmol})$ : orange powder $(0.58 \mathrm{~g}, 91 \%)$. IR (neat, $\mathrm{cm}^{-1}$ ): $v_{\max } 2960,1607,1586,1489,1404$, 1387, 1146, 953, 726. ${ }^{1} \mathrm{H}$ NMR $\left(\mathrm{C}_{6} \mathrm{D}_{6}, 200 \mathrm{MHz}\right): \delta 0.54(\mathrm{~d}, 6 \mathrm{H}$, $\left.{ }^{3} J_{\mathrm{H}-\mathrm{H}}=7.0 \mathrm{~Hz}, \mathrm{CHMe} 2\right), 0.65\left(\mathrm{~d}, 6 \mathrm{H},{ }^{3} \mathrm{~J}_{\mathrm{H}-\mathrm{H}}=7.0 \mathrm{~Hz}, \mathrm{CHMe} 2\right)$, $3.23\left(\mathrm{sp} \mathrm{d}, 2 \mathrm{H},{ }^{3} J_{\mathrm{H}-\mathrm{H}}=7.2 \mathrm{~Hz}, 2.8 \mathrm{~Hz}, \mathrm{CHMe}_{2}\right), 3.63(\mathrm{~m}, 2 \mathrm{H}$, $\mathrm{NCH}), 3.95\left(\mathrm{~m}, 4 \mathrm{H}, \mathrm{OCH}_{2}\right), 6.63\left(\mathrm{t}, 1 \mathrm{H},{ }^{3} J_{\mathrm{H}-\mathrm{H}}=7.0 \mathrm{~Hz}, \mathrm{ArH}\right)$, $6.98\left(\mathrm{~d}, 2 \mathrm{H},{ }^{3} J_{\mathrm{H}-\mathrm{H}}=7.4 \mathrm{~Hz}, \operatorname{Ar} H\right) .{ }^{13} \mathrm{C}\left\{{ }^{1} \mathrm{H}\right\} \mathrm{NMR}\left(\mathrm{C}_{6} \mathrm{D}_{6}, 75\right.$ $\mathrm{MHz}): \delta 13.8\left(\mathrm{CMe}_{2}\right), 18.6\left(\mathrm{CMe}_{2}\right), 29.5\left(\mathrm{CMe}_{2}\right), 66.1(\mathrm{NCH})$, $72.4\left(\mathrm{OCH}_{2}\right), 124.0(\mathrm{ArC}), 124.4(\mathrm{ArC}), 129.9(\mathrm{ArC}), 173.1(\mathrm{ArC})$, $173.3(\mathrm{OCN})$.

Synthesis of $(S, S)-\left[\mathrm{NiBr}(t-\mathrm{Bu}, \mathrm{H}-\mathrm{Phebox})\left(\mathrm{PEt}_{3}\right)_{2}\right] \quad(7 \mathrm{c})$ via Route A. $n$-BuLi (1.3 mL, $2.08 \mathrm{mmol}, 1.6 \mathrm{M}$ solution in hexanes) was added to a solution of $\mathbf{5 c}(0.74 \mathrm{~g}, 1.82 \mathrm{mmol})$ in THF $(25 \mathrm{~mL})$ at $-78{ }^{\circ} \mathrm{C}$. After stirring for $10 \mathrm{~min}$, the deep red solution was added dropwise to a solution of $\left[\mathrm{NiBr}_{2}\left(\mathrm{PEt}_{3}\right)_{2}\right](0.83 \mathrm{~g}, 1.82 \mathrm{mmol})$ in diethyl ether $(30 \mathrm{~mL})$ at $-78{ }^{\circ} \mathrm{C}$. The reaction mixture was warmed to room temperature. After stirring for $16 \mathrm{~h}$, the dark brown reaction mixture was dried in vacuo and dissolved in toluene (50 $\mathrm{mL}$ ). After centrifugation, the supernatant was separated. The precipitate was extracted with toluene $(20 \mathrm{~mL})$. The mixture was dried in vacuo and centrifugated after addition of pentane $(50 \mathrm{~mL})$. The supernatant was separated and dried in vacuo, which afforded a brown oil $(0.99 \mathrm{~g}, 77 \%)$. A small quantity was further purified by crystallization from pentane at $-20{ }^{\circ} \mathrm{C}$, which yielded the product as a dark red powder. ${ }^{1} \mathrm{H}$ NMR $\left(\mathrm{C}_{6} \mathrm{D}_{6}, 300 \mathrm{MHz}\right): \delta$ $0.91\left(\mathrm{~m}, 18 \mathrm{H}, \mathrm{P}\left(\mathrm{CH}_{2} \mathrm{CH}_{3}\right)_{3}\right), 1.01$ (s, $\left.18 \mathrm{H}, \mathrm{CMe}_{3}\right), 1.55(\mathrm{~m}, 12 \mathrm{H}$, $\left.\mathrm{P}\left(\mathrm{CH}_{2} \mathrm{CH}_{3}\right)_{3}\right), 4.17\left(\mathrm{~m}, 4 \mathrm{H}, \mathrm{OCH}_{2}\right), 4.45\left(\mathrm{t}, 2 \mathrm{H},{ }^{3} \mathrm{~J}_{\mathrm{H}-\mathrm{H}}=9.2 \mathrm{~Hz}\right.$, $\mathrm{CHN}), 6.77\left(\mathrm{t}, 1 \mathrm{H},{ }^{3} J_{\mathrm{H}-\mathrm{H}}=7.7 \mathrm{~Hz}, \operatorname{Ar} H\right), 8.18\left(\mathrm{~d}, 2 \mathrm{H},{ }^{3} J_{\mathrm{H}-\mathrm{H}}=\right.$

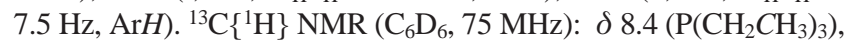
$16.1\left(\mathrm{t},{ }^{1} J_{\mathrm{C}-\mathrm{P}}=11.3 \mathrm{~Hz}, \mathrm{P}\left(\mathrm{CH}_{2} \mathrm{CH}_{3}\right)_{3}\right), 26.4\left(\mathrm{CMe}_{3}\right), 34.2\left(\mathrm{CMe}_{3}\right)$, $68.9(\mathrm{CHN}), 76.4\left(\mathrm{OCH}_{2}\right), 122.0(\mathrm{ArC}), 132.1(\mathrm{ArC}), 137.0(\mathrm{ArC})$, $162.8(\mathrm{ArC}), 166.8(\mathrm{CN}) .{ }^{31} \mathrm{P}\left\{{ }^{1} \mathrm{H}\right\}$ NMR $\left(\mathrm{C}_{6} \mathrm{D}_{6}, 81 \mathrm{MHz}\right): \delta 1.4$. Anal. Calcd for $\mathrm{C}_{32} \mathrm{H}_{57} \mathrm{BrN}_{2} \mathrm{NiO}_{2} \mathrm{P}_{2}$ : C, 54.72; H, 8.18; N, 3.99. Found: C, 54.63; H, 8.07; N, 4.06.

Synthesis of [NiBr(Me,Me-Phebox)] (2a) via Route B. To a stirred suspension of $\mathrm{Ni}(\operatorname{cod})_{2}(258 \mathrm{mg}, 0.94 \mathrm{mmol})$ in THF (30 $\mathrm{mL})$ at $-78{ }^{\circ} \mathrm{C}$ was added [Me,Me-PheboxBr] (5a) (363 mg, 1.0 $\mathrm{mmol})$ in THF $(10 \mathrm{~mL})$. The mixture was warmed to room temperature overnight. The mixture was centrifuged and separated. The supernatant was dried in vacuo and washed with pentane. The solid orange residue was characterized by ${ }^{1} \mathrm{H}$ NMR spectroscopy as pure $\mathbf{2 a}(318 \mathrm{mg}, 83 \%) .{ }^{1} \mathrm{H}$ NMR $\left(\mathrm{C}_{6} \mathrm{D}_{6}, 300 \mathrm{MHz}\right): \delta 1.49(\mathrm{~s}$, $\left.12 \mathrm{H}, \mathrm{CMe}_{2}\right), 3.59\left(\mathrm{~s}, 4 \mathrm{H}, \mathrm{OCH}_{2}\right), 6.69\left(\mathrm{t}, 1 \mathrm{H},{ }^{3} J_{\mathrm{H}-\mathrm{H}}=7.5 \mathrm{~Hz}\right.$, $\operatorname{ArH}), 6.98\left(\mathrm{~d}, 2 \mathrm{H},{ }^{3} \mathrm{~J}_{\mathrm{H}-\mathrm{H}}=7.2 \mathrm{~Hz}, \operatorname{Ar} H\right)$.

Synthesis of $(S, S)$-[NiBr(i-Pr,H-Phebox)] (2b) via Route B. An analogous procedure to the synthesis of $\mathbf{2 a}$ was employed with 5b (623 $\mathrm{mg}, 1.64 \mathrm{mmol})$ and $\left[\mathrm{Ni}(\mathrm{cod})_{2}\right](432 \mathrm{mg}, 1.57 \mathrm{mmol})$ : yellow-orange powder (697 mg, quant.). ${ }^{1} \mathrm{H}$ NMR $\left(\mathrm{C}_{6} \mathrm{D}_{6}, 300\right.$ $\mathrm{MHz}): \delta 0.54\left(\mathrm{~d}, 6 \mathrm{H},{ }^{3} J_{\mathrm{H}-\mathrm{H}}=7.2 \mathrm{~Hz}, \mathrm{CHMe} 2\right), 0.65\left(\mathrm{~d}, 6 \mathrm{H},{ }^{3} J_{\mathrm{H}-\mathrm{H}}\right.$ $=7.2 \mathrm{~Hz}, \mathrm{CHMe}$ ), $3.22\left(\right.$ septet d, $2 \mathrm{H},{ }^{3} \mathrm{~J}_{\mathrm{H}-\mathrm{H}}=7.0 \mathrm{~Hz}, 2.7 \mathrm{~Hz}$, $\left.\mathrm{CHMe}_{2}\right), 3.64(\mathrm{~m}, 2 \mathrm{H}, \mathrm{CHN}), 3.95\left(\mathrm{~m}, 4 \mathrm{H}, \mathrm{OCH}_{2}\right), 6.63(\mathrm{t}$, $\left.1 \mathrm{H},{ }^{3} J_{\mathrm{H}-\mathrm{H}}=7.0 \mathrm{~Hz}, \operatorname{Ar} H\right), 6.98\left(\mathrm{~d}, 2 \mathrm{H},{ }^{3} J_{\mathrm{H}-\mathrm{H}}=7.2 \mathrm{~Hz}, \operatorname{Ar} H\right)$.
${ }^{13} \mathrm{C}\left\{{ }^{1} \mathrm{H}\right\}$ NMR $\left(\mathrm{C}_{6} \mathrm{D}_{6}, 75 \mathrm{MHz}\right): \delta 13.8\left(\mathrm{CHMe} e_{2}\right), 18.6(\mathrm{CHMe} 2)$, $29.5\left(\mathrm{CHMe}_{2}\right), 66.1(\mathrm{CHN}), 72.4\left(\mathrm{OCH}_{2}\right), 124.0(\mathrm{ArC}), 124.4$ $(\mathrm{ArC}), 129.9(\mathrm{ArC}), 173.1(\mathrm{ArC}), 173.3(\mathrm{OCN})$. Anal. Calcd for $\mathrm{C}_{18} \mathrm{H}_{23} \mathrm{BrN}_{2} \mathrm{NiO}_{2}$ : C, 49.36; H, 5.29; N, 6.40. Found: C, 49.38; H, 5.36; N, 6.33.

Synthesis of $(S, S)$-[NiBr(t-Bu,H-Phebox)] (2c) via Route B. An analogous procedure to the synthesis of $\mathbf{2 a}$ was employed with 5c $(250 \mathrm{mg}, 0.61 \mathrm{mmol})$ and $\left[\mathrm{Ni}(\mathrm{cod})_{2}\right](160 \mathrm{mg}, 0.58 \mathrm{mmol})$ : yellow-orange powder $(0.162 \mathrm{~g}, 60 \%)$. ${ }^{1} \mathrm{H}$ NMR $\left(\mathrm{C}_{6} \mathrm{D}_{6}, 300\right.$ $\mathrm{MHz}): \delta 0.93\left(\mathrm{~s}, 18 \mathrm{H}, \mathrm{CMe} e_{3}\right), 3.58\left(\mathrm{t}, 2 \mathrm{H},{ }^{3} J_{\mathrm{H}-\mathrm{H}}=7.8 \mathrm{~Hz}, \mathrm{CHN}\right)$, $3.83\left(\mathrm{~d}, 2 \mathrm{H},{ }^{3} J_{\mathrm{H}-\mathrm{H}}=7.5 \mathrm{~Hz}, \mathrm{OCH}_{2}\right), 4.04\left(\mathrm{~d}, 2 \mathrm{H},{ }^{3} J_{\mathrm{H}-\mathrm{H}}=7.5 \mathrm{~Hz}\right.$, $\left.\mathrm{OCH}_{2}\right), 6.63\left(\mathrm{t}, 1 \mathrm{H},{ }^{3} J_{\mathrm{H}-\mathrm{H}}=7.1 \mathrm{~Hz}, \operatorname{Ar} H\right), 6.96\left(\mathrm{~d}, 2 \mathrm{H},{ }^{3} J_{\mathrm{H}-\mathrm{H}}=\right.$ $6.6 \mathrm{~Hz}, \mathrm{Ar} H) .{ }^{13} \mathrm{C}\left\{{ }^{1} \mathrm{H}\right\}$ NMR $\left(\mathrm{C}_{6} \mathrm{D}_{6}, 75 \mathrm{MHz}\right): \delta 26.9\left(\mathrm{CMe}_{3}\right)$, $35.6\left(\mathrm{CMe}_{3}\right), 68.5(\mathrm{CHN}), 75.1\left(\mathrm{OCH}_{2}\right), 124.1(\mathrm{ArC}), 124.2(\mathrm{ArC})$, $130.1(\mathrm{ArC}), 170.6(\mathrm{ArC}), 173.9(\mathrm{OCN})$. Anal. Calcd for $\mathrm{C}_{20} \mathrm{H}_{27} \mathrm{BrN}_{2} \mathrm{NiO}_{2}$ : C, 51.54; H, 5.84; N, 6.01. Found: C, 51.28; H, 5.97; N, 5.84.

Synthesis of 2,6-Bis[ $N-2^{\prime}, 6^{\prime}$-dimethylphenyl)ketimino]phenylnickel(II) Bromide (3) via Route B. A solution of 6 (171 mg, $0.38 \mathrm{mmol})$ in THF $(10 \mathrm{~mL})$ was added to a solution of $\left[\mathrm{Ni}(\operatorname{cod})_{2}\right]$ in THF $(15 \mathrm{~mL})$ at $-60^{\circ} \mathrm{C}$. The reaction mixture was stirred for 3 days (at room temperature), after which it was centrifuged, the supernatant removed, and the residue extracted with THF $(25 \mathrm{~mL})$. The THF was removed in vacuo. The residue was washed with pentane $(2 \times 7 \mathrm{~mL})$, yielding a bright orange solid, which was characterized as pure $3\left(128 \mathrm{mg}, 72 \%\right.$ ). IR (neat, $\mathrm{cm}^{-1}$ ): $v_{\max } 2965$, 1576, 1534, 1465, 1333, 1261, 1092, 1017, 786, 766. ${ }^{1} \mathrm{H}$ NMR (300 MHz, $\mathrm{C}_{6} \mathrm{D}_{6}$ ): $\delta 1.32$ (s, 6H, NCMe), 2.27 (s, 12H, ArMe), $6.82(\mathrm{~m}, 3 \mathrm{H}, \operatorname{Ar} H), 6.92(\mathrm{~m}, 6 \mathrm{H}, \operatorname{Ar} H) .{ }^{13} \mathrm{C}\left\{{ }^{1} \mathrm{H}\right\} \mathrm{NMR}(75 \mathrm{MHz}$, $\left.\mathrm{C}_{6} \mathrm{D}_{6}\right): \delta 15.9(\mathrm{NCMe}), 19.33(\mathrm{ArMe}), 123.0(\mathrm{ArC}), 125.7(\mathrm{ArC})$, $126.5(\mathrm{ArC}), 128.2(\mathrm{ArC}), 128.4(\mathrm{ArC}), 130.5(\mathrm{ArC}), 145.5(\mathrm{ArC})$, 147.3 (ArC), 180.3 (ArC), 185.3 (NCMe). Anal. Calcd for $\mathrm{C}_{26} \mathrm{H}_{27} \mathrm{BrN}_{2} \mathrm{Ni}$ : C, 61.70; H, 5.38; N, 5.54. Found: C, 61.61; H, $5.33 ; \mathrm{N}, 5.42$.

Typical Polymerization Experiment. Ethyl-2-bromoisobutyrate $(11.5 \mu \mathrm{L}, 0.078 \mathrm{mmol})$ was added to a mixture of $\mathbf{2 a}(32 \mathrm{mg}, 0.077$ $\mathrm{mmol}$ ) and degassed MMA (2.0 mL, $19 \mathrm{mmol})$ in toluene $(7.5 \mathrm{~mL})$ at $90{ }^{\circ} \mathrm{C}$. The mixture was stirred for $16 \mathrm{~h}$ and then analyzed by ${ }^{1} \mathrm{H}$ NMR spectroscopy. No color change was observed (orange). Polymerization: $0 \%$.

Kharasch Addition. $\mathrm{CCl}_{4}(10 \mathrm{~mL}, 104 \mathrm{mmol})$ was added to a mixture of $2 \mathbf{a}(32 \mathrm{mg}, 0.077 \mathrm{mmol})$ and degassed methyl methacrylate $(3.0 \mathrm{~mL}, 28 \mathrm{mmol})$ in $\mathrm{CH}_{2} \mathrm{Cl}_{2}(10 \mathrm{~mL})$ at room temperature. The mixture was stirred for $16 \mathrm{~h}$ and then analyzed by ${ }^{1} \mathrm{H}$ NMR spectroscopy. No change of color was observed (orange). Conversion: $0 \%$.

Cyclic Voltammetry. Cyclic voltammetry measurements were performed with an Autolab PGSTAT 10 cyclic voltammeter, using a Pt working electrode and a $\mathrm{Ag} / \mathrm{AgCl}$ reference electrode in acetone with tetrabutylammonium bromide $(0.1 \mathrm{M})$ as supporting electrolyte, at scan rates ranging from 0.025 to $1 \mathrm{~V} / \mathrm{s}$. Under these conditions the ferrocene/ferrocenium $\left(\mathrm{Fc} / \mathrm{Fc}^{+}\right)$couple was located at +0.44 $\mathrm{V}$ with a peak separation of $80 \mathrm{mV}$.

$\mathrm{X}$-ray Crystal Structure Determination of $(\mathrm{S}, \mathrm{S})$-[ $\mathrm{NiBr}(\boldsymbol{i}-\mathrm{Pr}, \mathrm{H}-$ Phebox)] (2b). $\mathrm{C}_{18} \mathrm{H}_{23} \mathrm{BrN}_{2} \mathrm{NiO}_{2}, \mathrm{fw}=438.00$, yellow plate, 0.18 $\times 0.12 \times 0.03 \mathrm{~mm}^{3}$, monoclinic, $P 2_{1}$ (no. 4), $a=6.2846(7) \AA, b$ $=12.0673(5) \AA, c=12.0639(13) \AA, \beta=100.695(8)^{\circ}, V=899.01$ (14) $\AA^{3}, Z=2, \rho=1.618 \mathrm{~g} / \mathrm{cm}^{3} ; 36365$ reflections up to a resolution of $(\sin \theta / \lambda)_{\max }=0.51 \AA^{-1}$ were measured on a Nonius KappaCCD diffractometer with rotating anode and graphite monochromator $(\lambda=0.71073 \AA)$ at a temperature of $150(2) \mathrm{K}$. The crystal appeared to be nonmerohedrally twinned with a 2-fold rotation about $h k l(10 \overline{2})$ as twin operation. This direction is approximately parallel to the $\mathrm{Ni}-\mathrm{Br}$ bond. The intensity data were evaluated with EvalCCD,${ }^{37}$ taking the twin relation into account.

(37) Duisenberg, A. J. M.; Kroon-Batenburg, L. M. J.; Schreurs, A. M. M. J. Appl. Crystallogr. 2003, 36, 220. 
An analytical absorption correction was applied $\left(\mu=3.314 \mathrm{~mm}^{-1}\right.$, $0.55-0.89$ correction range), and the reflections were merged according to the twin law, resulting in 7979 unique reflections $\left(R_{\text {int }}\right.$ $=0.0637)$. The structure was solved with automated Patterson methods (DIRDIFF-99 ${ }^{38}$ ) based on the nonoverlapping reflections of the first twin domain. The structure was then refined as a HKLF$5^{39}$ twin with SHELXL-9740 on $F^{2}$ of all reflections, resulting in a twin fraction of $0.5141(4) ; 222$ parameters were refined with one restraint for the origin shift in the polar space group. $R_{1} / w R_{2}[I>$ 2o(I)]: $0.0328 / 0.0611 . R_{1} / w R_{2}$ [all reflns]: $0.0492 / 0.0656 . S=$ 1.022. Flack $x$ parameter: ${ }^{41}-0.008(6)$. Residual electron density was between -0.36 and $0.64 \mathrm{e} / \AA^{3}$. Structure calculations, drawings, and checking for higher symmetry were performed with the PLATON $^{42}$ package.

X-ray Crystal Structure Determination of [NiBr(bis(ketimine)phenyl)] (3). $\mathrm{C}_{26} \mathrm{H}_{27} \mathrm{BrN}_{2} \mathrm{Ni}$, fw $=506.12$, red needle, $0.42 \times$ $0.09 \times 0.09 \mathrm{~mm}^{3}$, monoclinic, $P 2_{1} / c$ (no. 14), $a=11.7638(1) \AA$, $b=10.9956(1) \AA, c=18.2973(1) \AA, \beta=101.7010(3)^{\circ}, V=$ 2317.57(3) $\AA^{3}, Z=4, \rho=1.451 \mathrm{~g} / \mathrm{cm}^{3} ; 55626$ reflections up to a resolution of $(\sin \theta / \lambda)_{\max }=0.65 \AA^{-1}$ were measured on a Nonius KappaCCD diffractometer with rotating anode and graphite monochromator $(\lambda=0.71073 \AA)$ at a temperature of $150(2) \mathrm{K}$. An absorption correction based on multiple measured reflections was applied $\left(\mu=2.576 \mathrm{~mm}^{-1}, 0.58-0.79\right.$ correction range); 5318 reflections were unique $\left(R_{\text {int }}=0.0468\right)$. The structure was solved with automated Patterson methods (DIRDIF-99 ${ }^{38}$ ) and refined with SHELXL-9740 on $F^{2}$ of all reflections. Non-hydrogen atoms were refined freely with anisotropic displacement parameters. All hydrogen atoms were located in the difference Fourier map and refined as rigid groups; 277 parameters were refined without restraints. $R_{1} / w R_{2}[I>2 \sigma(I)]: 0.0321 / 0.0736 . R_{1} / w R_{2}$ [all reflns]: 0.0461/0.0793. $S=1.036$. Residual electron density was between -0.91 and $0.80 \mathrm{e} / \AA^{3}$. Structure calculations, drawings, and checking for higher symmetry were performed with the PLATON ${ }^{42}$ package.

$\mathrm{X}$-ray Crystal Structure Determination of $\left[\mathrm{NiBr}_{2}(\mathrm{NCN})\right](8)$. $\mathrm{C}_{12} \mathrm{H}_{19} \mathrm{Br}_{2} \mathrm{~N}_{2} \mathrm{Ni}$, fw $=409.82$, monoclinic, space group $P 2{ }_{1} / c, a=$ 13.7870(16) $\AA, b=7.6995(9) \AA, c=14.7377(17) \AA, \beta=110.337$ $(3)^{\circ}, V=1466.9(3) \AA^{3}$ (by least-squares refinement on 6099

(38) Beurskens, P. T.; Admiraal, G.; Beurskens, G.; Bosman, W. P.; Garcia-Granda, S.; Gould, R. O.; Smits, J. M. M.; Smykalla, C. The DIRDIF99 program system, Technical Report of the Crystallography Laboratory; University of Nijmegen: The Netherlands, 1999. 443.

(39) Herbst-Irmer, R.; Sheldrick, G. M. Acta Crystallogr. 1998, B54,

(40) Sheldrick, G. M. SHELXL-97, Program for Crystal Structure Refinement; Universität Göttingen: Germany, 1997.

(41) Flack, H. D. Acta Crystallogr. 1983, A39, 876 reflection positions), $T=220(2) \mathrm{K}, \lambda=0.71073 \AA, Z=4, D$ (calcd) $=1.856 \mathrm{Mg} / \mathrm{m}^{3}, F(000)=812, \mu(\mathrm{Mo} \mathrm{K} \alpha)=6.751 \mathrm{~mm}^{-1}$. Crystal character: dark block. Crystal dimensions: $0.50 \times 0.28 \times 0.12$ $\mathrm{mm}$. Data collection and processing: Siemens SMART ${ }^{43}$ threecircle system with CCD area detector. The crystal was held at 220(2) K with the Oxford Cryosystem cryostream cooler. ${ }^{44}$ Maximum theta was $28.88^{\circ}$. The $h k l$ ranges were $-18 / 12,-10 / 10,-16 / 19$; 8704 reflections measured, 3539 unique $\left[R_{\text {int }}=0.0325\right]$. Semiempirical absorption correction from equivalents; maximum and minimum correction factors: $0.54 ; 0.89$. No crystal decay. Structure analysis and refinement: Systematic absences indicated $P 2_{1} / c$ and were shown to be correct by successful refinement. The structure was solved by direct methods using SHELXS-9745 (TREF) with additional light atoms found by Fourier methods. Hydrogen atoms were added at calculated positions and refined using a riding model with freely rotating methyl groups. Anisotropic displacement parameters were used for all non- $\mathrm{H}$ atoms; $\mathrm{H}$ atoms were given isotropic displacement parameters equal to 1.2 (or 1.5 for methyl hydrogen atoms) times the equivalent isotropic displacement parameter of the atom to which the $\mathrm{H}$ atom is attached. The weighting scheme was $w=1 /\left[\sigma^{2}\left(F_{\mathrm{o}}{ }^{2}\right)+(0.0339 P)^{2}\right]$ where $P=$ $\left(F_{\mathrm{o}}{ }^{2}+2 F_{\mathrm{c}}{ }^{2}\right) / 3$. Goodness-of-fit on $F^{2}$ was $0.927, R_{1}$ [for 2681 reflections with $I>2 \sigma(I)]=0.0322, w R_{2}=0.0711$. Data/restraints/ parameters: $3539 / 0 / 159$. Extinction coefficient: 0.0004(2). Largest difference Fourier peak and hole: 0.65 and $-0.50 \mathrm{e} / \AA^{3}$. Refinement used SHELXTL. ${ }^{46}$

Acknowledgment. We thank Prof. Dr. B. Hessen and Dr. P. Chase for their suggestions and stimulating discussions. Prof. Dr. J. Reedijk and Dr. E. Bouwman are acknowledged for their hospitality at Leiden University. R.W.A.H. acknowledges financial support from the Netherlands Organization for Scientific Research (NWO), grant 700.53.401, and NWO/NCF for use of supercomputer time on TERAS/ASTER, SARA (The Netherlands, project number SG-032). G.C. thanks EPSRC and Siemens Analytical Instruments for grants in support of the diffractometer.

\section{OM061055Y}

(42) Spek, A. L. J. Appl. Crystallogr. 2003, 36, 7.

(43) SMART User's Manual; Siemens Industrial Automation Inc.: Madison, WI.

(44) Cosier, J.; Glazer, A. M. J. Appl. Crystallogr. 1986, 19, 105.

(45) Sheldrick, G. M. Acta Crystallogr. 1990, A46, 467.

(46) Sheldrick, G. M. SHELXTL, Ver. 5.1; Bruker Analytical X-ray Systems: Madison, WI, 1997. 